\title{
Identifying Policy Frames through Semantic Network Analysis: An Examination of Nuclear Energy Policy across Six Countries ${ }^{1}$
}

\author{
Junseop Shim ${ }^{2}$ \\ Chisung Park (Corresponding Author) ${ }^{3}$ \\ Mark Wilding 4
}

\begin{abstract}
This study uses semantic network analysis to investigate nuclear energy policy frames in six countries: USA, UK, Germany, France, Japan, and South Korea. It is suggested that semantic network analysis represents a useful tool to investigate policy frames in complex policy environments. The discourse of top-level decision makers is analyzed to highlight similarities and differences in policy frames and to identify the key policy arguments in the integrated network of all six countries. In total, 14 major policy arguments are identified, which relate to the three major frames of energy security, clean energy, and nuclear safety, along with the metaissue of economic growth. There are differences in the degree of emphasis on each of the frames in the six countries, and Germany can be seen to have diverged the most following the Fukushima accident, as the emphasis is on clean energy, to the exclusion of the other frames. In contrast, both the USA and Japan have framed the issues primarily in terms of nuclear safety and energy security, while the UK and France have stressed the economic growth frame, and Korea has prioritized nuclear safety.
\end{abstract}

Key words: Policy frame; Text network analysis; Frame analysis; Nuclear energy policy

\footnotetext{
1 This is an Accepted Manuscript of an article accepted for publication by Springer US in Policy Sciences. The latest version is available online at https://doi.org/10.1007/s11077-015-9211-3

2 School of Public Service, Chung-Ang University, Seoul, Korea

3 School of Public Service, Chung-Ang University, Seoul, Korea. Contact: csp7111@gmail.com

4 School of Nursing, Midwifery, Social Work \& Social Sciences, University of Salford, Manchester, UK
} 


\section{Introduction}

Post-positivistic approaches are increasingly recognized as having much to offer policy analysis (Fischer and Gottweis, 2012). From this perspective, complexity is regarded as one of the bases to explore public policy (Lejano, 2006). In particular, due to the political dimensions of the policy process there may be multiple perspectives (and interpretations) of the same policy issue (Dunn, 2003; Stone, 1988). These interpretations are based on the policy frames through which a policy problem and its context are constructed (Schön and Rein, 1994).

Still, the major schools of policy analysis have tended to focus on how policy-makers undertake rational choices from among policy alternatives. These dominant approaches largely focus on decision processes for optimal allocation of public resources, and as such, aim to develop techniques to compare alternative ways of achieving specific policy goals so as to identify the optimal means (Stokey and Zeckhauser, 1978; Dunn, 2003). Instrumental rationality has therefore been central to the development and adoption of policy alternatives.

Viewed from this perspective, it has been argued that the rational choice approach has done little to enhance the overall understanding of political interaction (Green and Shapiro, 1994). In particular, the rational choice approach has difficulties accounting for policy actors' making sense of situations and issues. This is problematic as the outcomes of the policy process vary significantly depending upon how policy actors with bounded rationality construct and understand the situation they face (Stone, 1988). Indeed, it should be emphasized that policy-making is not a process of solving problems according to rational and technical criteria (Dayton, 2000; Schön and Rein, 1994). Rather, the "reality" constructed and perceived by policy actors plays a critical role in explaining how they behave in the policy process. The "frames" that govern policy actors' understanding of policy problems can be understood as the building blocks which guide these perceptions.

Since Goffman's (1974) seminal work on the concept of frames, many researchers have viewed policy frames as a starting point to analyze complex policy processes (Saarikoski, 2006; Fischer, 2003; Laws and Rein, 2003; Schön and Rein, 1994). These researchers have employed a variety of analytical techniques to identify policy frames based on diverse theoretical and methodological foundations. Consequently, frame analysis should not be regarded as a unified methodology but rather a diverse range of methods to analyze discourse, including content analysis, narrative analysis, and discourse analysis (Scheufele, 1999).

Still, the extent to which these methods can be used to accurately identify policy participants' mental 
structures has been questioned. More specifically, these approaches have been criticized for being too generic and not providing the analytic tools to support their own findings about frames (Lukeš, 2007). As such, this study suggests that semantic network analysis has the potential to more accurately identify policy frames and to contribute to bridging the shortcomings of other frame analysis approaches. In this regard, this study analyzes policy actors' frames through semantic network analysis. In particular, energy policy discourses across six major nuclear generating countries (USA, UK, Germany, France, Japan, and South Korea) with significant nuclear power programmes are investigated (see Appendix 1).

Discourse on nuclear power is ongoing and changes over time, especially when actors attempt to interpret and understand accidents (Gamson and Modigliani, 1989). More specifically, nuclear energy represents an appropriate policy area for investigation through frame analysis for the following reasons. First, debates concerning nuclear power pros and cons are prevalent around the world. Since even a small radioactive leak could have tremendous consequences, the risks associated with nuclear power cannot be overestimated, as evidenced by the Fukushima accident. Still, nuclear power is regarded as an environmentally friendly energy source since it reduces greenhouse gas emissions and thus reduces pollution. It is also more efficient than any other energy sources. As a result of these important but unsolvable concerns, each country's nuclear agenda and orientation have been governed by political discourse and societal values at the national level.

Second, nuclear power policy should not be considered as a domestic policy bound by national territories, because of potential overspill risks. Yet, countries continue to design and implement policies largely based on domestic political, economic, and social conditions. More specifically, each country has according to its own context developed different policy stances and frames toward nuclear energy utilization (Teräväinena, Lehtonenb, and Martiskainen, 2011). Thus, it is relatively difficult to achieve shared nuclear power policy goals across several countries. In order to understand the national situations and to promote agreement, it is necessary to have information on the similarities and differences in policy orientations. Frame analysis of policy actors in different countries represents a way of providing this information.

More specifically, this study analyzes the nuclear power policy addresses and speeches of top decisionmakers from six countries. In doing so, we aim to understand the similarities and differences between the countries, and produce useful policy insights in the nuclear power field. Semantic network analysis is applied as a potentially useful technique to reveal the hidden meaning of texts, as well as the shared meanings among different actors, by applying the socio-cognitive network concept (Carley, 1990). 
There has long been an interest in cross-national comparisons of nuclear energy policies, including the countries sampled in the present study. For example, comparisons have been undertaken of West Germany and the USA (Joppke, 1991), France and the USA (Daemen, 1993; David and Rothwell, 1994; Delmas and Heiman, 2000), France, Finland and the UK (Teräväinena,et al., 2011), and the USA and Sweden (Nohrstedt, 2005). In addition, a handful of studies have focused on framing and reframing in nuclear energy, for example Bickerstaff et al. (2008) and Corner et al. (2011) examined citizen framing of nuclear policy in the UK. Despite their unique contributions, however, these studies did not provide a comprehensive comparison among major countries with nuclear policies and programs. More importantly, how each country shaped its own nuclear energy frames following the Fukushima accident and how they differ from before have not been fully addressed. The present study therefore aims to contribute to the comparative literature on nuclear energy policy and on the framing of nuclear energy, while simultaneously highlighting the utility of semantic network analysis to identify policy frames.

\section{The Changing Landscape in National Nuclear Policies}

Nuclear discourse on energy policies are typically conceived as being contextually embedded (Teräväinen et al., 2011). Each country's energy policy has unique features in terms of policy problems and environment, and the paths of policy evolution reflect historical and political contexts. In addition, although the Fukushima accident enticed some nations such as Germany to phase out nuclear power, economic considerations would still be the deciding force (Bradford, 2012). Economic factors including the security of energy supplies and energy prices have played important roles in determining the relative viability of nuclear power. In particular, since the "oil shocks" of the early 1970s, energy security has been prioritized in most countries with few natural resources including France, the UK, Japan, and Korea.

It is important to note that environmental issues are discussed from the perspective of international energy governance. More specifically, mitigating climate change and reducing $\mathrm{CO}_{2}$ emissions have relatively recently become important issues in international energy discourse (Corner et al. 2011). In 1992, countries joined an international treaty, the United Nations Framework Convention on Climate Change (UNFCC), and subsequent Kyoto protocol in 1997 to cooperatively limit climate change (UNFCC, 2014). The aim of reducing greenhouse gas emissions has meant that nuclear countries have supported an increase in renewable energy sources and/or 
nuclear power (EIA, 2013). In particular, nuclear energy was viewed as an option to combat climate change, to secure energy supplies, and to achieve sustainable development for most nuclear countries (Sirin, 2010). International organizations including the UN and the International Atomic Energy Agency (IAEA) also came to play very important roles in driving international cooperation to strengthen the global nuclear safety framework (IAEA, 2014). However, as will be discussed below, the countries that have fostered nuclear energy for electricity generation for decades have faced different domestic and international energy policy environments. While the Fukushima accident had a profound impact on the world's environment, economy, and energy policy (Schneider et al., 2013), national policy frames and solutions have differed widely.

In Germany, nuclear power has been a top political issue in recent decades, with continuing debates about when the nuclear plants should be phased out. The topic received renewed attention at the start of 2007 due to the political impact of the Russia-Belarus energy dispute and again in 2011 after the Fukushima accident. In 1998 , the coalition government revealed plans to phase-out nuclear power by 2022, but in 2009 a 12 year delay was announced. Since Germany has relied on nuclear power for $23 \%$ of its energy, the phase-out would present huge challenges for the national economy and industrial structure, and the government decided to use nuclear as a "bridging technology" to a greener future (BBC News, 2011; Burgermeister, 2009). However, the Fukushima accident provided the German government a political umbrella to accelerate phase-out (Srinivasan and Gopi Rethinaraj, 2013), and the benefits of competitive advantage in the renewable energy market have been emphasized (Associated Press, 2011).

France has vigorously pursued nuclear development, largely to achieve energy independence despite few natural resources. Experiencing energy crisis with the "oil shock" in the 1970s, French policy-makers chose a strategic route to energy independence through nuclear energy (Palfreman, 2009). The goals of energy independence and being a net exporter of electricity have been used in efforts to win public support for nuclear programmes (Sastry and Siegel, 2010). As a result, France now has the most sophisticated and expansive nuclear energy programmes and enjoys a substantial level of energy independence, with energy costs among the lowest of the European Union. Recently, economic factors have been of utmost importance when considering energy policy. In particular, job creation has been urgent following the Eurozone economic recessions (BBC News, 2013). Under the circumstances, despite the Fukushima accident, it is expected that France will remain committed to nuclear energy without notable policy changes (Srinivasan and Gopi Rethinaraj, 2013). 
Nuclear has been one of the most important energy sources in the UK. However, the country is a net electricity importer, mainly from France. In 2007 the Labour government changed its policy stance from opposing to approving new nuclear power plants, and highlighted the role of nuclear plants in a low carbon mix (DTI, 2007). Thus, nuclear power was viewed as not only a means to enhance energy security but as a clean energy source that would satisfy future energy needs and contribute to mitigating climate change (Pidgeon et al., 2008; Corner et al., 2011). Government policy on nuclear power has remained largely unchanged since then; even the Fukushima accident did not derail plans to replace old reactors with new ones (WEC, 2012). Indeed, the UK government sees itself as at the forefront of the "nuclear renaissance" (UK Government, 2013). With the most ambitious de-carbonization targets in the world with $80 \%$ reduction of greenhouse gas emissions by 2050 (HM Government, 2008), the UK is likely to continue developing nuclear energy while working towards $\mathrm{CO}_{2}$ reduction.

As another country with limited natural resources, the 1973 oil crisis led Japan to prioritize energy independence and therefore the strategic development of nuclear energy. Prior to the 2011 accident, Japanese nuclear power had been viewed as a success story (Bradford, 2012). However, Japanese nuclear policy has since come to face a different domestic and international policy environment (Vivoda, 2012; Hayashi and Hughes, 2013). The government subsequently accepted as inevitable a fundamental change in its nuclear safety systems (SEOMUN XIV Chair Research Report, 2011). There were strong calls from the public for the abandonment of nuclear policies; trade-off margins between benefits and risks of nuclear power, socially acceptable prior to the accident, no longer existed (Srinivasan and Gopi Rethinaraj, 2013). Under the circumstances the Democratic Party of Japan (DPJ) government announced a shift in energy policy through a slow phase-out of nuclear power by 2030. However, due to the fragility of Japan's energy security (IEE Japan, 2012), in March 2013, new Prime Minister Shinzo Abe pledged to conduct a zero-based review of the long-term nuclear phase-out policy. Apparently, given the extremely low energy self-sufficiency rate of $4 \%$ without nuclear power, Japan has limited policy options for ensuring its future energy security (Vivoda, 2012; Wilson Center, 2012; Itoh, 2013). Simply put, the Japanese government has to find imaginative ways of balancing strong public opposition with energy security through the continued development of nuclear energy.

In Korea, since the long-term economic development plans of the 1960s, nuclear energy has been a strategic priority from the perspective of energy security and energy production efficiency (WNA, 2014). In 2010, the Korean government announced the aim of exporting 80 nuclear reactors by 2030, and thus to become the 
world's third largest supplier of nuclear technology (WNN, 2010). In November 2011 after the Fukushima accident, the Korean government confirmed again its commitment to nuclear energy and the construction of six new reactors by 2016 (Bradford, 2012). Indeed, due to its deemed strategic importance, the Korean government decided to pursue nuclear energy development in the face of public opposition. However, this has been accompanied by establishing the Nuclear Safety and Security Commission as a new independent regulatory agency in 2011, with the aim of strengthening safety and regulations, and thereby reducing the public's risk perception and ultimately opposition.

The Atomic Energy Act of 1954 was the symbolic beginning of private nuclear development in the US (Daemen, 1993), and the nuclear industry underwent tremendous expansion until the mid-1970s. The US abandoned the nuclear option around 1974, however, due to 1) revised forecasts of nuclear energy demand, 2) escalation of public opposition, and 3) shifting production costs (Daemen, 1993). As a result, nearly $50 \%$ of nuclear facilities were cancelled, rejected, or delayed infinitely, and no new nuclear power plants have been constructed since 1977. Further, the Three Mile Island disaster of 1979 led the US government to reduce nuclear investment, effectively ending progress in the development of civilian nuclear energy technology (Wilson Center, 2012). Since then, the US has lacked political consensus on energy policy, except for broad agreement on the necessity of strict nuclear regulation (Sastry and Siegel, 2010). More recently, US energy policy has shifted increasingly to natural gas. Under the "shale gas revolution" it is predicted that natural gas will be the most used fuel in the US by 2030 (Wilson Center, 2012). However, in late 2013, the Nuclear Regulatory Commission (NRC) was reviewing nine applications to construct 14 new nuclear power plants. It should also be noted that in June 2013, President Obama announced a plan to fight climate change, which raised the importance of carbon emissions. Under the circumstances, the Fukushima disaster has had little direct impact on the future of the nuclear energy discourse in the US (WEC, 2012), except more stringent safety regulation and delays in licensing new nuclear plants (Srinivasan and Gopi Rethinaraj, 2013). Currently, although nuclear might not be at the forefront of future energy policy discourse, the US would continue its commitment to nuclear energy (WNA, 2014).

\section{Frame Analysis Approaches in Policy Analysis}

In policy analysis, three major schools of thought have evolved over the decades: the traditional school of 
policy science, the school of politics, and the consensual dispute resolution school (Schön and Rein, 1994). Though they are based on different theoretical and epistemological foundations, they share assumptions about instrumental rationality. They assume that policy actors including policy-makers choose the best means to achieve their goals. Nevertheless, these three schools have not only failed to explain the intractability of policy disputes but also to provide possible solutions to the disputes (Schön and Rein, 1994).

Recently, as an alternative to the three schools of thought, frame analysis has gained momentum. Schön and Rein (1994) suggested that policy analysis can only be effective through taking conceptual framing into account. Frame analysis emphasizes that each actor's policy position rests on underlying structures of belief, perception, and conceptualization (i.e., frames). Framing refers to the process by which people develop a particular conceptualization or reorient their thinking about an issue (Chong and Druckman, 2007). More specifically, a policy frame refers to considerations regarding certain features and implications of the policy issue. When developing a policy argument, politicians may deliberately attempt to formulate a policy frame by highlighting certain features of reality and by employing metaphors, stories, and discourses (Dayton, 2000; Saarikoski, 2006). However, competing policy frames can convey contrasting and often incompatible views of reality, and policy actors with different policy frames may clash.

Frames are most clearly detectable through policy actors' discourse on a policy situation and issue. Based on van Dijk’s (1977) definition of discourse, policy discourses can be considered to be comprised of policy addresses, speeches and dialogue about policy issues. Yet, language is not a neutral system of communication, because it is always based on frames, conceptual metaphors, and stories (Lakoff, 1996). Indeed, Majone (1989: 1) noted that, "public policy is made of languages" of which the central role is to deliver argument, and emphasized that formal speech aims both to clarify the decision maker's political position and to persuade audiences to accept this position. Therefore, policy frames can be captured by analyzing core arguments in policy texts collected from written or oral forms of policy discourse. As noted above, a number of diverse frame analysis techniques have been utilized since the seminal work of Goffman (1974), including content analysis (Chong and Druckman, 2007, 2011), narrative analysis (van Eeten, 2007), and most of all, discourse analysis (Schön and Rein, 1994; Hajer, 1995; Scheufele, 1999; Dayton, 2000; Saarikoski, 2006). However, there is little consensus on how to identify frames.

Although policy frame researchers do not share a unified frame analysis technique, it is possible to categorize policy frame analysis into quantitative and qualitative approaches as presented in Table 1. Drawing 
on the deductive approach, quantitative frame researchers believe that a frame can be crystallized explicitly and objectively through keywords and terms in a discourse. They examine frames that were defined and operationalized prior to the analysis. To this end, they analyze policy discourses through quantitative measures of keywords and terms as indicators of frames (Entman, 1993; Cappella and Jamieson, 1997; Triandafyllidou and Fotiou, 1998; Semetko and Valkenburg, 2000), by measuring the tone of keywords and terms (i.e., pro/anti), and classifying arguments according to predefined frames (Baumgartner, Boef, and Boydstun, 2008). In a similar vein, some suggest themes, metaphors, exemplars, catch-phrases, depictions, and visual images as framing devices (Gamson and Modigliani, 1989; Nelson, Clawson, and Oxley, 1997). Despite significant contributions, quantitative frame researchers have been criticized for being over-dependent on specific words and terms while neglecting contexts and underlying meanings of arguments.

In comparison, more studies have been conducted using qualitative frame analysis. In these studies (e.g., Schön and Rein, 1994; Hajer, 1995; Creed, Langstraat, and Scully, 2002; Lewicki, Gray, and Elliott, 2003), frames are usually identified implicitly through researchers' subjective interpretation of stories and discourses, using techniques borrowed from discourse analysis and sociolinguistics. Qualitative studies also tend to be inductive as they do not attempt to make predictions through theoretical frameworks with a priori defined policy frames. Instead, frames emerge from the text during the process of analysis. This approach has been criticized for not providing an objective way to operationalize and measure frames and due to the difficulties of replicating findings (Hertog and McLeod, 2001).

\section{Table 1 to Feature Here}

As noted above, both approaches have not provided appropriate tools for the concrete identification of policy actors' frames. Despite ongoing methodological debates, most frame researchers agree that policy frames can be crystalized through policy stories and discourses. On this basis, this study attempts to combine quantitative and qualitative methods to analyze policy frames through semantic network analysis.

\section{Semantic Network Analysis as a Method for Frame Analysis}

Since the early 1990s, network analysis of text data has become a widely used method in various academic 
fields including sociology (Carley, 1993), political science (Maynard, 1997; Kim, Su, \& Hong, 2011), information science (Popping, 2003; Diesner and Carley, 2004; Doerfel and Connaughton, 2009), computer science (Diesner, 2012), communications (Rice and Danowski, 1993; Jang and Barnett, 1994; Doerfel, 1998; Doerfel and Barnett, 1999; Kwon et al., 2009; Doerfel and Marsh, 2003; van Atteveldt et al., 2008), conflict management (Young, 1996), poetics (Carley, 1994), and linguistics (Smith, 2003; Smith and Humphreys, 2006). As a result, many different theories and methods have been developed for text-based network analysis and there is no single agreed method and designation of the analysis in the literature (Doerfel, 1998; Diesner, 2012).

Nevertheless, most previous studies using text data for network analysis can be categorized into three groups depending upon the information extracted (Diesner, 2012). First, concept networks, often called semantic networks, can be extracted (Sowa, 1984; Rice \&Danowski, 1993; Jang and Barnett, 1994; Carley, 1997a, 1997b; Doerfel and Barnett, 1999; Popping, 2000, 2003; Smith, 2003; Smith and Humphreys, 2006; Doerfel \& Marsh, 2003; Doerfel and Connaughton, 2009; Kwon et al., 2009; Carley et al., 2011). In these networks, nodes (i.e., concepts) represent salient information from a body of text and concepts (i.e., words) are "abstract representation of the information that people conceive in their minds" (Diesner, 2012: 5). Therefore, by analyzing links between concepts, the researcher can extract implicit meaning and interpret structural properties from networks of words. In this way, researchers attempt to extract and distill more fundamental meanings or abstract information embedded in text (Carley, 1994, 1997b). Second, multi-mode networks called metanetworks can be extracted, where nodes represent entities of social systems such as people, groups, locations, and resources (Carley, 2002; Diesner and Carley, 2004; van Atteveldt et al., 2008; Diesner, 2012). Finally, texts or documents can themselves be used as nodes and tied to the social agents (Hummon and Doreian, 1989; Moody, 2004). Of these three types, the present study focuses on semantic network analysis, primarily due to its capacity to extract salient information from text, to describe relationships among concepts, to analyze underlying meanings in text, and to understand the structure of concept networks (Danowski, 1982, 1993; Carley and Palmquist, 1991; Rice \& Danowski, 1993; Carley, 1997a, 1997b; Jang and Barnett, 1994; Doerfel, 1998; Popping, 2000, 2003;Doerfel and Marsh, 2003; Diesner and Carley, 2004; Doerfel and Connaughton, 2009; Diesner, 2012). ${ }^{5}$

Drawing on the literature, semantic network analysis in this study is defined as network analysis using

${ }^{5}$ Similarly, Salisbury (2001) and Sherblom et al. (2001) analyzed salient words, image, cognitive construct, and meanings using neural network content analysis. 
written texts to identify salient words and concepts and further to extract underlying meanings and frames from the structure of concept networks. While traditional text analysis (i.e., content analysis) relies on measuring frequencies in order to find the most prominent concepts (Krippendorff, 2004), semantic network analysis can identify structural properties through recognition of relations between concepts (i.e., co-occurrence) by applying network analysis techniques. Through utilization of semantic network analysis, this study explores diverse structural properties such as bridging between concepts and sub-structures of the text, the interrelations of terms, and the most frequently mentioned concepts (Jang and Barnett, 1994; Carley, 1997a, 1997b; Diesner and Carley, 2004, 2005; Kwon, 2009; Doerfel and Connaughton, 2009).

Further, the methodological capacity of social network analysis to reveal hidden patterns behind social phenomena (Wasserman and Faust, 1994; Scott, 2000) enables semantic network analysis to identify the implicit or embedded meanings and structure in a text. In other words, semantic network analysis can "generate new, logically implied statements that may not be explicitly stated in texts" (Roberts, 1997: 6). This is more than just "reading between the lines," however, as it uses an objective and quantitative approach to reveal the hidden patterns (Doerfel and Marsh, 2003). Semantic network analysis firstly measures the substructures of the text, before integrating them to induce the main meaning in the text.

Like other types of network, concept networks are composed of subgroups or (local) communities which are tightly knit with many relations inside communities and only a few relations between communities (Newman, 2010). Through detecting these substructures and identifying bridging concepts which play a meaning circulation role in the entire network, it is possible to understand the main argument of a text (i.e., the policy frame) and compare differences between different texts.

As a raw data source for semantic network analysis, policy texts are composed of chains of arguments, which are in turn composed of sub-claims and supporting evidence (Toulmin, Rieke, and Janik, 1984). In order to understand the main argument of a policy text, it is necessary to simultaneously understand the sub-claims in the text and the contribution of these to the main claim. Semantic network analysis enables this understanding through identification of concepts with a meaning circulation role, and through using modularity analysis to disassemble texts into the substructures in which local claims are nested (Newman, 2006), before integrating the sub-claims. ${ }^{6}$

\footnotetext{
${ }^{6}$ Similarly, statistical analysis techniques such as multidimensional scaling (MDS), cluster analysis, correspondence analysis, discriminant analysis (Jang and Barnett, 1994), correlation analysis, and spatial
} 
Sub-claims can be integrated through the identification of bridging concepts between local communities across the whole network. Though the sub-claim of each local community remains unchanged, bridging concepts between two or more sub-claims allow us to make sense of the various sub-claims that otherwise may appear fragmented. Thus, bridging concepts assist the circulation of meaning between local communities.

Terms with a meaning circulation role can be identified through centrality analysis, which uses degree and betweenness centrality to measure a concept's influence in the network (Freeman, 1979). Concepts with high degree centrality play a connector role, indicating the extent to which they are connected to other adjacent concepts (i.e., the number of times they co-occur with other words). Concepts with high betweenness centrality play a bridge or gatekeeper role between other concepts in the network.

Concepts can be categorized into four different types, depending on the level of degree and betweenness centrality, as presented in Table 2. First, high-ranking concepts in both categories of centrality can be understood as hubs (especially if the degree distribution follows power-law), and their role is to circulate meaning across the entire network (Paranyushkin, 2011, 2012). The meaning circulation role can be emphasized if the betweenness centralization index $(\mathrm{BCI})^{7}$ is high, because this means that there are a small number of central concepts.

\section{Table 2 to Feature Here}

Second, concepts with high degree centrality but comparatively low betweenness centrality can be read as local hubs in the community, because they have a relatively high number of adjacent relationships, which means the connecting role is limited to local actors, and concepts in other communities are not reliant on this concept to connect together. Third, concepts with high betweenness centrality but relatively low degree centrality can be seen as bridges between local communities. In contrast to the local hub, this concept does not have much influence on adjacent concepts, but many other concepts in various communities could connect together only via this concept. Fourth, concepts that are comparatively low in both categories of centrality are regarded as

modeling as a more advance version of MDS (Kwon et al., 2009) can be used for determining relations among concepts and grouping them through statistical analyses.

7 BCI measures how centralized the betweenness of the set of actors is (i.e., whether communication in the community depends on one member or many. A BCI reaches its maximum value of 1 when all actors in the network are dependent on one actor to communicate with each other and "its minimum value (0) occurs when all actors have exactly the same actor betweenness index" (Wasserman and Faust, 1994: 192). 
peripheral concepts which do not play a meaning circulation role.

This study also proposes that shared or overlapping meaning among different actors can be detected through socio-cognitive networks, which integrate individual cognitive networks (Carley, 1997b). This is significant, as it is only possible to pursue collective solutions when policy actors reach a shared understanding of the same policy issue (Stone, 1988). As such, policy theories have grappled with the issue of how policy actors with different and sometimes conflicting value systems can make adjustments to arrive at a mutual understanding. Semantic network analysis could help to find a shared meaning by combining the respective networks (i.e., individual cognitive networks) into one integrated network (i.e., socio-cognitive network). A challenge is that the meaning of a specific concept could differ when used by individuals in contrasting contexts, because "concepts' structural characteristics are not fixed but dependent on the sociocultural environment and the task being performed" (Carley, 1997b: 99). However, if texts can be collected from across the population and an integrated network is built using this population text, we could identify the overall interrelationships between the concepts. In this integrated network, all of the relationships between concepts overlap, which represents all the possible connections between concepts. Thus, variety in the meaning of concepts diminishes (differences are offset and there is convergence towards the average meaning), and the social meaning of concepts can emerge from the integrated network.

Since there is no widely agreed upon method for the construction of integrated text networks, this study applies an exploratory approach. More specifically, concepts used in the integrated network analysis are selected using the following criteria: (1) concepts used by more than two countries, and (2) in the case of concepts used in a single country, only concepts which occur more than three times are included.

\section{Research Design}

\section{Case Selection}

The national nuclear energy policy frames of USA, UK, Germany, France, Japan, and Korea are all included in this study. Each of these countries has harnessed nuclear energy for electricity generation for decades, though this has been challenged to varying degrees since the Fukushima accident. The "big five" nuclear generating countries, which generate approximately $67 \%$ of the world's nuclear electricity are the United States, France, Russia, South Korea and Germany. Russia was excluded from this study due to data accessibility. Instead, Japan 
and the UK were included as Japan experienced the Fukushima nuclear disaster in 2011, and nuclear generation in the UK peaked in the 1990s. In addition, the countries selected are geographically representative, being situated in Europe, North America and Asia. Furthermore, nuclear power plant accidents have occurred in all six countries though to varying degrees (SEOMUN XIV Chair Research Report, 2011).

Further, nuclear policies before and after the Fukushima accident are compared to examine the extent to which this event affected nuclear policy orientations. Four countries were selected for pre-post comparisons: the UK, US, Germany, and Japan. These countries were selected from within the larger sample according to data availability and in order to check whether the Fukushima accident influenced overall patterns of nuclear policy orientation.

\section{Data Collection}

To explore and compare nuclear energy policy frames in the six countries, policy discourses from top-level decision makers were used as text data for analysis. More specifically, formal speeches by top-level decisionmakers about energy policy were utilized. These represent an appropriate source of data, as based on van Dijk's (1977) definition, policy discourses can be seen to be comprised of policy addresses, speeches and dialogue about policy issues.

Methodologically, it is important to show the individual texts to be representative of the nation's policy because "one official's speech ... is likely to be slightly ... different from that of another official, even if they belong to the same administration" (van Eeten, 2007: 253). This difference can be minimized by using the most representative or collective level of speeches, which usually come from the President, Prime Minister or Minister of the energy related department. Speeches from these sources can be seen as representative of national energy policy, rather than an individual perspective. In order to further reduce bias related to the audience, speech-writer, or other factors, multiple speeches over a period of time are analyzed ${ }^{8}$.

This study used formal speeches made before and after the March 2011 Fukushima accident, the most critical event in recent years with the potential to influence the orientation of nuclear power policy. More specifically, events in Fukushima may have clarified nuclear energy policy orientations; if a government

\footnotetext{
${ }^{8}$ For example, in the case of Germany, excerpts from an energy summit speech (15 April, 2011) and an interview with Zeit (12 May 2011) were combined for post Fukushima accident frame analysis, while interviews with FAZ (25 February 2010), Bild am Sonntag (13 June, 2010), Frage (7 July 2010), Süddeutsche Zeitung (September 29 2010), and Focus (8 November 2010) were combined for pre Fukushima accident frame analysis.
} 
maintained a positive stance towards nuclear power despite the accident, this would highlight the extent to which they wanted to maintain nuclear power as their main electricity source, and vice versa. In addition, although their orientations are different in nature, displays of sympathy or concern following the accident could be a starting point for policy convergence.

Specifically, this study analyzed the speeches and addresses of top-level policy-makers in the six countries. These documents were collected from official government websites; researchers used "nuclear" and "energy" as keywords to search for appropriate speeches to analyze within the time range of June 2009-September 2013. Text data were retrieved from each country's national archives, and after reading all of the speeches, extracts were selected for analysis. Excerpts were chosen according to the following criteria: paragraphs containing 1) keywords such as nuclear and energy, 2) discussion of policy orientation, and 3) discussion of policy opinions regarding the Fukushima accident. Then, these parts were combined into a text for semantic network analysis (see Appendix 5).

\section{Measurements}

For the purpose of network analysis, texts were coded into nodes (i.e., concepts or words) and ties between a pair of nodes (i.e., co-occurrence within a sentence and/or paragraph), which resulted in an $\mathrm{n} x \mathrm{n}$ matrix. In conducting semantic network analysis, it is necessary to avoid the subjective influences of the author (Paranyushkin, 2011). As such, to understand the relationships between concepts in the text, the objective meaning of the concepts should be applied, rather than subjective meanings suggested by the author because the structure of the text appears more clearly when the meaning is neutralized (Derrida, 1978). This study regards the same concepts across the speeches to maintain the same meaning. For example, nuclear energy or energy security in the US speech delivers the same meaning as in Germany or Japan as the top-level decision makers in this study are government representatives and not likely to use subjective meaning of concepts in their formal speeches. More specifically, excerpts from all 45 texts were preprocessed following the steps suggested by Danowski (1993) and Paranyushkin $(2011,2012)$. This involved removing all the stopwords (e.g., a, the, is), normalizing past and future tenses, and transforming semantically connected terms into a representative word. In order to conduct these steps, AutoMap software was used, as it was developed for the purpose of preprocessing texts for network analysis (Carley et al., 2007, 2011).

Ties are defined as the co-occurrence of concepts within a limited range of text such as a clause, sentence, 
paragraph or the whole text. This study limited the range of co-occurrence to a sentence because, by definition ${ }^{9}$, a sentence is a group of words made to deliver meaning. Thus, words in a sentence may form a node or be connected together as they are made to impart the same point. It is important to note that ties are undirected because they are based upon co-occurrence. When two words occur consecutively, they are considered to be connected $^{10}$. For the actual analysis, two programmes were used: Gephi for the modularity analysis, and UCINET to calculate the degree and betweenness centralization index.

\section{Results}

\section{Description of Network Structural Properties}

Table 3 presents the structural properties of the six countries' networks. First, network size (i.e., number of nodes and ties) varies across the countries from the largest network of France to the smallest network of Japan. However, structural properties of network, such as the average degree per concept, network diameter, and average path length, do not differ to any great extent.

\section{Table 3 to Feature Here}

Second, while there is relatively little variation in the degree centralization index, there are large differences in the betweenness centralization index. In the US and Germany the highest ranked concepts according to betweenness centrality are "nuclear" and "energy" respectively, and these terms are dominant in that approximately half of all the flows between concepts are dependent upon these words. In contrast, the highest ranked concepts by betweenness centrality in the UK and France (i.e., "will” and "nuclear" respectively) charge only one fifth of all meaning flows in their networks.

Third, since modularity is high across all texts, it can be said that the networks are partitioned by tightly-knit communities (i.e., dense connections within communities, but sparse connections between communities).

In the networks of the US, UK, France, and Korea, "nuclear" and similarly "nuclear-power plant" in that of

\footnotetext{
9 The following definition of sentence was used: "a grammatical unit consisting of one or more words that are grammatically linked. A sentence can include words grouped meaningfully to express a statement, question, exclamation, request,commandorsuggestion".(http://en.wikipedia.org/wiki/Sentence_(linguistics))

10 A coding example is illustrated in Appendix 4.
} 
Japan turned out to be the most influential concept in terms of betweenness centrality, whereas "energy" is the most influential concept in Germany. These are the concepts that connect different communities within the respective networks and therefore play a bridging role. It is important to note that the same concepts were found to be the most influential in the tests of the UK, US, Germany, and Japan prior to the Fukushima accident. Appendix 2 reveals there to be relatively little variation in the network properties for these countries prior to the Fukushima accident.

\section{Nuclear Energy Policy Frames of the Six Countries}

Table 4 presents the major sub-groups of the concept networks in the six countries after the Fukushima accident. The policy arguments on nuclear energy in the US can be summarized as "Nuclear energy as a clean source of electricity generation" in the largest community, while the second largest community suggests that "Nuclear power plant would unlock civil commitment and demands". Dealing with the other countries in turn, the largest community in the UK appears to be arguing that "The UK should build new nuclear projects for the energy market and economy", while the second largest community suggests that the "government will decarbonize the power sector through the nuclear industry”. In Germany the largest communities put forward the case that "The consensus for the future is that Germany will invest in renewable energy technology rather than nuclear", and that "For nuclear power plants it is time to decide whether to extend the expiration plan" respectively. The largest community in France suggests hesitant support for nuclear power. In particular, that "Nuclear energy has risks but provides choice for (industrial) sector interests and energy security" and that "(Nuclear) electricity at the right safety level boosts the economy and competitiveness". In Japan the policy argument in the largest community can be summarized in the phrase "Japan will take responsibility and meet expectations based on fundamental decisions", while there is also a strong sentiment that "Japan should boost cooperation with relevant countries". The arguments of the two main communities in Korea are that "Growth in energy demand contributes to demand for alternatives and (energy) independence" and "Korea makes efforts for the safety of future nuclear use with global cooperation".

\section{Table 4 to Feature Here}

By examining degree and betweenness centrality of the concepts in terms of structural role in the concept 
networks, salient concepts can be identified as having international influence (i.e., they play a hub or bridging role in more than two countries). "Nuclear" plays a hub or meaning circulation role in the network of all of the countries with the exception of Japan. While "energy" plays a central role in the US, Germany, France and Korea, it is more important as a local hub in Japan, and is relatively less influential in the UK. "Will” plays a hub role in UK, Japan and France, and "new" can be seen to play a hub role in the US and the UK. Although "safety" also plays a hub role in Korea, in Japan it is most prominent as a local hub. In Japan "nuclear power plant" and "nuclear power" are bridging concepts that aid meaning circulation, but in Germany the same concepts act more as local hubs. Several terms can be identified as influential in single countries. For example, in Germany "consensus" is a bridging concept that connects communities, and "renewable" seems to play a hub role. "Accident" plays a bridge role in Korea, while "reactor" plays a hub role in France, and "clean" and "nation" play hub roles in the US.

By combining influential concepts with sub-groups, it is possible to identify national nuclear energy policy frames. Dealing with the US first, it appears that nuclear energy is perceived as a clean source of electricity that can be unlocked through the development of techniques to improve safety. In the UK, the government sees nuclear power as meeting the needs of the energy market and providing opportunities for economic growth based on partnerships between the UK government and industry, as well as overseas investment. Although energy needs are an important concern in Germany, there is a growing consensus that the time has come to phase-out nuclear energy and to invest in renewable energy technologies. Interestingly, the safety of nuclear power is not a high ranking concept in Germany, although "disaster" is. The frame in France is mixed as it contains risk and an awareness of costs and that a decision must be made, but also discussion of the benefits of nuclear power in terms of energy security and the economy. In Japan there is an awareness of the need to be responsible as well as the need to consider nuclear safety for international cooperation. Yet, nuclear energy is still seen as an important means of promoting energy security. The Korean government sees energy independence and nuclear safety as central, and there is discussion of past and potential accidents. Simultaneously, there are efforts to strengthen the nation's capacity to provide nuclear power, as well as to promote confidence in nuclear energy safety through putting events into a global context and emphasizing the role of the IAEA.

Through comparing policy arguments across the six countries, similarities and differences between the frames can be identified. In terms of similarities, safety concerns appear to be shared by all of the countries, although in Germany the talk is of disaster. With the exception of Japan, there is particular concern about the nuclear concept 
itself and whether it presents the best way forward, as seen with the high ranking of "nuclear" for both degree and betweenness centrality in five of the six countries. At the same time there is also an awareness of the potential of nuclear power to meet needs for energy security. Turning to the differences, it appears that Germany has diverged the most, as it is concerned to move out of nuclear energy, while the other countries have maintained their interest. However, there is also a degree of variation between France and the UK, which are particularly interested in the economic benefits, and the USA, Japan, and Korea which see nuclear power more as a way of meeting energy needs.

\section{Comparison of Nuclear Energy Policy Frames before and after the Fukushima Accident}

For the UK, US, Germany, and Japan, comparisons were made to examine the differences in policy arguments before and after the Fukushima accident. Appendix 3 presents the major sub-groups of the concept networks prior to the Fukushima accident. In the US, the largest community posits that "as nuclear industry energy sources grow, this demands expertise and leadership". The second community indicates that "nuclear power plants will create more jobs for the country than plants that use coal fuel". In the largest community in the UK, the policy argument can be summarized as "there is potential for companies to create energy supplies and relieve the fuel challenge," whereas in the second community the implication is that "the policy is to build nuclear capacity as industry is willing to make new investments." In Germany, the largest community states "we have long planned and decided to significantly expand and extend the networks we talk to." In the second largest community, the argument is that "we have reached the end of the nuclear age so the policy is to quickly promote renewable energy." In Japan, the largest community seemingly argues for "strengthened commitment to nuclear materials as a sign of our energy security around the world," while the second community is keen to point out that "foreseen and actual $\mathrm{CO}_{2}$ emission levels from stations have been established."

Table 5 compares influential concepts before and after the Fukushima accident for the four countries. Despite the Fukushima accident, "Nuclear Energy" was the same important concept in the US, as was "Nuclear Industry" in the UK, "Renewable Energy" in Germany respectively, while "Cooperation" was important in Japan. However, there are also differences. In the US, while "Nuclear Energy" was related to the concepts "Investment" and "job" before the accident, it was connected with "Climate" "Change" after the accident. In the case of Japan, while "Nuclear" and "Nuclear-power" was described with the concepts "Peaceful", "Energy" before the accident, the same words are connected with "Safety", "Energy" after the accident. The replacement 
of "Bridge" with "Disaster" and "Consensus" in Germany suggests that Fukushima helped to galvanize opinion against nuclear energy. In the UK, change can also be seen, albeit towards opportunities the nuclear industry can bring.

\section{Table 5 to Feature Here}

Accordingly, it can be noted that the policy arguments after the Fukushima accident to a large extent are similar to those before the accident. Displaying strong path dependency, the US has seen nuclear energy as a clean energy source and a means for boosting economy irrespective of the Fukushima accident. While the US government framed nuclear energy and nuclear power plants mainly in terms of economic benefits before the accident, it subsequently tried to re-frame them in terms of an alternative to reduce greenhouse gas emissions. Showing similar degree of path dependency, the UK continued to be interested in nuclear energy from the perspective that nuclear industry could potentially help address fuel challenges, while Germany maintained a strong interest in environmental concerns and Japan energy security. There are also some differences in the way that the decommissioning of power plants was no longer referred to in any of the UK government's key policy arguments, although even prior to the Fukushima accident this was accompanied by cost considerations. In Germany, a swift move away from nuclear energy can be detected with the dropping of terms such as "bridging technology" in favour of "expiration" and "investment in renewable energy". In Japan, discussion of $\mathrm{CO}_{2}$ emissions and the role of the private sector were no longer included in the largest communities as the arguments begun to focus more on responsibility and safety.

\section{Exploring Shared Meanings among the Six Countries}

This section explores the integrated semantic network in order to (1) identify the overall nuclear policy frames, (2) compare these with policy frames from the six countries, and (3) find shared meanings among the six countries. For the integrated network, the top 30 salient concepts according to both degree and betweenness centrality are ranked in Table 6. "Nuclear", "Energy", "Will" are the most influential and meaning circulating concepts both before and after the Fukushima accident. This indicates that policy arguments are primarily concerned with discussion of the nuclear concept and how they intend to meet energy needs. Other concepts such as "Investment", "Nuclear-Power" maintain their influence in both tests. As expected, the importance of 
"Safety" increases after the accident. In addition, "Electricity" and "Challenge" also become relatively more influential. Before the accident, "Renewable", "Carbon", "Security" and "Emission" were relatively important concepts, but after the accident, these words become less influential. Concepts such as "Industry", "Build", "Continue", and "Technology" play the role of local hubs after the accident because they are relatively high in degree centrality, but lower in betweenness centrality. This suggests that continuing to develop nuclear power plants and associated technology is also an important policy argument within the integrated network. Finally, concepts that bridge communities include "issue", "plan", "security", and "economy". This highlights the extent to which governments need to be seen to have clear strategies to maintain energy security and economy, particularly as "safety" and "investment" are also high ranking concepts.

\section{Table 6 to Feature Here}

The most influential concepts in the local communities of the integrated network are summarized in Table 7. The argument in Community 1 can be understood as suggesting that "The UK remains interested in continuing the programme to build and use new plants to enhance the sector and industry and supply nuclear security". In Community 2, the argument can be summarized as "Progress in this area to meet these goals will improve capability and be a better way to provide benefits for the economy, country and people". Community 3 appears to support nuclear as a clean energy source "The policy is to secure considerable investment from business to develop nuclear power systems with the potential to ensure clean and safe electricity generation as an energy resource", while Community 4 is concerned more with energy security: "Sharing lessons from the Fukushima accident in Japan, it is time to decommission the expired and this is the best position to restart and extend, there is a responsibility to protect nuclear power plants in the area". In Community 5 the argument is that: "Serious talk about problems can increase consideration of needs and focus on prospects". Clean energy is again emphasized in Community 6: "The conclusion is that there are limitations to fossil and carbon fuels and we support the implementation of an exit", while similar arguments are made in Community 7: "Today we launch strong efforts to enhance our contribution to the question of how to mitigate climate change". In Community 8 the emphasis is more on nuclear safety: "We seek public understanding through reviewing and communicating the dangers and peaceful uses". Communities 9 and 10 are of the same size and are both concerned with sustaining economic growth. Although Community 9 emphasizes the private sector: "The government choice is 
to plan to promote the greatest private sector commitment and to consistently advance the market over the long term for citizens", Community 10 is more concerned with growth and jobs generally: "Fundamentally, this is a global opportunity for discussions to consider management and how to improve economic growth, work and jobs". Community 11 stresses that: "There is a community consensus on renewables and a decision to reduce the level of risk from coal and gas power plants and $\mathrm{CO}_{2}$ emissions". In Community 12 nuclear safety is reflected upon: "The disaster strengthened progress in IAEA and world cooperation as well as commitment to regulatory and safety standards", and this is also the case in Community 13: "An element of the policy response is to recommend independent assessment and audit of facilities and help with technology and training of skilled operators". Finally, in Community 14, economics is again the primary concern: "In France the challenge and objective is to control the material price issue for future cost measure reasons".

\section{Table 7 to Feature Here}

Finally, through combining the centrality analysis (Table 6) with the investigation of the network substructures (Table 7), the overall policy frame can be identified. In the wake of the Fukushima accident, for the countries with nuclear power programmes, the rigorous debates over nuclear energy became entangled with three issues including public attitudes toward nuclear energy, the security of energy supplies, and the reduction of greenhouse gas emissions (Corner et al. 2011; Birmingham Policy Commission, 2012). Faced with this new situation, all six countries had to find solutions to simultaneously tackle the three issues. More generally, each country was also in the process of recovering from economic recession or attempting to sustain economic development.

Each of the six countries focused on different aspects of nuclear energy debates arising from the Fukushima accident and, thus, framed its own nuclear energy discourse. Yet, comparing the overall policy frame with subframes of the six countries, shared or overlapping meanings can be narrowed down to four main nuclear energy policy frames (i.e., the energy security frame, clean energy frame, economic growth frame, and nuclear safety frame). As presented in Table 8, the 14 major policy arguments identified through analysis of local communities in the network can be situated within these four frames.

Table 8 to Feature Here 
As can be seen in Table 8-1, for the US, UK, Germany, and Japan the main four frames prior to the Fukushima accident were similar to the post-Fukushima frames. Interestingly, while the accident did appear to impact the frames, the effects have not been straightforward nor led to convergence. The UK showed some concern for nuclear safety before the accident, but this was outweighed by cost considerations. Following events in Fukushima the UK framed nuclear energy policy exclusively in terms of economic growth and clean energy, with more emphasis on the former. One explanation could be that the UK government sought to counter the widespread negative publicity. In Germany, the framing of nuclear energy policy continued to be defined by clean energy. However, as discussed above, there was a shift away from arguments for using nuclear energy as a stop-gap measure; the need for renewable energy supplies became more pressing. In Japan, prior to the Fukushima accident a range of policy frames were utilized to express support for nuclear energy, yet after the accident the clean energy and economic growth frames were minimized as government focused on energy security and nuclear safety. The US approached nuclear energy mainly from a clean energy perspective with some consideration for energy security and economic growth before the Fukushima accident, and this remained largely the same afterwards.

\section{Table 8-1 to Feature Here}

Still, there are shared meanings post-Fukushima. With the exception of Germany, the countries all appear to believe that nuclear can promote their energy security. Germany is joined in its interest in clean energy by the US, UK, and Korea, although within the latter group of countries the discourse reflects a concern with how to harness nuclear energy to these ends. There was also a shared interest among the UK, France, US, and Korea in increasing economic opportunities through building the nuclear industry and technologies to provide energy.

Nuclear safety remains a key concern in Japan and Korea where there is interest in cooperation to strengthen regulatory standards.

\section{Discussion and Conclusion}

This study has sought to contribute to the comparative literature on nuclear energy policy and framing, as well as to highlight the utility of semantic network analysis at identifying policy frames. While other studies 
have examined the framing of nuclear power among citizens (Bickerstaff et al., 2008; Corner et al., 2011), we have illustrated how leading policy-makers have framed nuclear energy policy in six major nuclear producers in the aftermath of the Fukushima accident. We also compared policy frames in four of the countries before and after events in Fukushima to examine the effects of the accident.

In doing so we have highlighted both similarities and differences between the countries. Under the changed policy environments after the accident, all the countries had to develop their own nuclear policy frames while focusing to varying extents on three main pillars of issues: increasing public trust in government and the nuclear industry, enhancing the security of energy supplies, and meeting their own $\mathrm{CO}_{2}$ reduction targets. At the same time, the countries had to negotiate recovery from the economic crisis. More specifically, as a leader in the future world renewable energy market, Germany re-emphasized the clean energy frame. Abandoning nuclear power as a "bridging technology," it decided to phase-out nuclear plants just after the Fukushima accident. The US and Japan have framed the issues primarily in nuclear safety and energy security terms, although the clean energy frame is also important in the US. The UK and France are particularly interested in the economic growth frame and have not sought to emphasize the nuclear safety frame, which has been given priority in Korea. These findings can be discussed in terms of the implications for nuclear energy policies in the countries with nuclear programs.

First, each country's nuclear energy policies displayed strong path dependency, even after the Fukushima accident. It would appear that a movement away from the pattern of energy policy was limited to a large extent by a mixture of two path dependent constraints: economic growth and energy security. These constraints insulated nuclear policy frames from sweeping changes in each country, since to diverge from established paths could result in unpredictable costs for energy security and national economy (Vivoda, 2012; Scholvin, 2014). In this regard, the Fukushima accident did not substantially affect the paths of nuclear energy discourses. Even Japan's energy policy is still seen to be on the same path following the disaster (Vivoda, 2012). Rather than making a drastic decision to close nuclear plants as in Germany, the other countries focused on enhanced safety measures according to the advice of international organizations such as the UN, IAEA, and WNO. Still, as revealed in the analysis, the nuclear energy frames were influenced more by domestic demands rather than international considerations.

Second, nuclear energy was strategically framed in relation to renewable energy sources in each country. Though nuclear energy was viewed as a green energy with the potential to help mitigate greenhouse gas 
emissions, these claims have not been thoroughly examined when compared to other renewable energy sources. On the other hand, a variety of technical and economic problems need to be solved before renewable energy sources are rolled-out on a large-scale. Given this uncertainty, nuclear power could be framed as a viable option for reducing $\mathrm{CO}_{2}$ emissions from fossil fuels (REIA, 2013). In this regard, the UK government has emphasized the role of nuclear energy in mitigating climate change; a strategy which was successful in shaping supportive attitudes among the public.

Third, given the degree of public interest and participation in energy policy governance, it is important to understand the debate over nuclear energy not just from technological perspectives, but also within its various contexts. This should be the most important consideration for nuclear power, which has been the subject of public scepticism and low trust. The results of the present study can feed into this process; nuclear energy can serve either as a bridge to an all-renewable economy as in Germany and the US or as a long-term solution by itself as in the UK (Sastry and Siegel, 2010), depending upon the economic, political, and environmental contexts of each country. Therefore, it is vital for each government to formulate its own national frame on nuclear energy which can resonate with other energy sources. As the countries with nuclear programmes continue to debate the future of their energy policies and programs, the ways in which policy frames are formulated helps determine their future direction. In particular, frames should be constructed in terms of a future energy mix that contributes to $\mathrm{CO}_{2}$ reduction, to energy security, and to economic growth, while enhancing nuclear safety.

Fourth, drawing on scientific arguments could be helpful in framing national discourse on nuclear energy and its safety, particularly in aiding general publics' sense making (Vink et al., 2012). A reason for this is because energy and nuclear power concerns differ from other policy issues in that they can be "epistemologically distant" from everyday experiences (Carolan, 2004; Vink et al., 2012). As nuclear safety has come to the fore post-Fukushima, pro-nuclear countries have faced concerns from citizens regarding whether nuclear power plants are safe enough to be maintained. In this situation, IAEA safety guarantees have been used strategically to strengthen policy legitimacy, as in Korea. Still, there is space for scientific arguments that seek to improve public understanding and lead to a more informed citizenry.

The other major aim of the study was to present the usefulness of semantic network analysis for identifying policy frames. In particular, this study attempted to combine quantitative and qualitative frame analysis techniques through a concept network based frame analysis. The results indicate that identifying frames through 
semantic network analysis could contribute to a better understanding of how similar and/or different the policy orientations of chief policy-makers are. Through this methodology, we could not only objectively identify the central words in each country's energy policy discourse, as in quantitative frame analysis, but were also able to analyze the hidden meanings of the community of words in an interpretive way as in qualitative frame analysis (Doerfel, 1998; Carley, 1997a, 1997b; Danowski, 1993; Paranyushkin, 2011, 2012). As such, semantic network analysis represents a valuable methodology which can combine the strengths of other types of frame analysis in the concrete identification of frames generated by policy actors.

Despite these contributions, the limitations of semantic network analysis need to be addressed. Most of all, the validation of the resulting networks would be difficult for densely connected large-scale networks (Diesner, 2012). More specifically, techniques for text pre-processing, node identification, and link construction, that must be decided before mining network structure from text data, could strongly influence the structure of resulting networks; different methods may produce different results (Carley, 1993). This indicates that techniques for semantic network analysis should be selected with care and be closely aligned with research questions and objectives. This study also applied undirected ties among words based on co-occurrence. Corman et al. (2013) argued, however, that directional links would provide a more accurate description of meaning than nondirectional links. This issue needs to be addressed more completely in future research. Finally, this study focused on analyzing the policy frames of leading policy-makers at the national level to compare similarities and differences in policy frames among the leading nuclear countries. However, other policy actors such as media and non-governmental organizations also make policy frames which could influence (inter-)national nuclear energy discourses. Further studies could utilize semantic network analysis with a wider range of actors within a particular country or examine in detail how the audience affects the framing of speeches. In this sense, semantic network analysis can contribute to improved understanding of the different nuclear energy policy frames and attempt to move towards shared goals. 


\section{References}

BBC News. (2011). Germany: Nuclear power plants to close by 2022. May 30, 2011. <http://www.bbc.co. uk/news/world-europe-13592208>

BBC News. (2013). French jobless rate climbs to highest level in 15 years. <http://www.bbc.com /news/business-22794313>

Associated Press. (2011). Germany decides to abandon nuclear power by 2022. Retrieved May, 30. 2011.

Baumgartner, F. R., Boef, S. D., \& Boydstun, A. (2008). The decline of the death penalty and the discovery of innocence. Cambridge University Press.

Bickerstaff, K. I. L., Pidgeon, N. F., Poortinga, W. \& Simmons. P. (2008). Reframing nuclear power in the UK energy debate: nuclear power, climate change mitigation, and radioactive waste. Public Understanding of Science, 17, 145-169.

Birmingham Policy Commission. (2012). The future of nuclear energy in the UK. University of Birmingham.

Bradford, P. (2012). The nuclear landscape. Nature, 483(March), 151-152.

Burgermeister, J. (2009). Germany: The world's first major renewable energy economy. RENEWABLE ENERGY WORLD.COM< http://www.renewableenergyworld.com/rea /news/article/2009/04/germany-the-worlds-first-major-renewable-energy-economy?cmpid=WNLWednesday-April8-2009>

Cappella, J. N., \& Jamieson, K. H. (1997). Spiral of cynicism: The press and the public good. New York: Oxford University Press.

Carley, K. M. (2002a). Smart agents and organizations of the future. In L. Lievrouw \& S. Livingstone (Eds.), The handbook of new media: Social shaping and consequences of ICTs (pp.206-220). Thousand Oaks, CA: Sage.

Carley, K. M. (1997a). Extracting team mental models through textual analysis. Journal of Organizational Behavior, 18, 533-558.

Carley, K. M. (1997b). Network text analysis: The network position of concept. In C. W. Roberts (Eds.), Text analysis for the social sciences: Methods for drawing statistical inferences from texts and transcripts (pp. 79-100). Mahwah, NJ: Lawrence Erlbaum Associates, Publishers.

Carley, K. M. (1994). Extracting culture through textual analysis. Poetics, 22, 291-312. 
Carley, K. M. (1993). Coding choices for textual analysis: A comparison of content analysis and map analysis. Sociological Methodology, 23, 75-126.

Carley, K. M. (1990). Group stability: A socio-cognitive approach. In W. Lawler, B. Markovsky, C. Ridgeway \& H. Walker (Eds.), Advances in group processes: Theory \& research. Vol. VII (pp. 1-44). Greenwhich, CN: JAI Press.

Carley, K. M., Columbus, D., Bigrigg, M., \& Kunkel, F. (2011). AutoMap user's guide 2011. Technical Report, CMU-ISR-11-108, Carnegie Mellon University, School of Computer Science, Institute for Software Research.

Carley, K. M., Diesner, J., Reminga, J., \& Tsvetovat, M. (2007). Toward an interoperable dynamic network analysis toolkit. Decision Support Systems. Special Issue Cyberinfrastructure for Homeland Security, 43(4), 1324-1347.

Carley, K. M., \& Palmquist, M. (1991). Extracting, representing, and analyzing mental models. Social Forces, $70(3), 601-636$.

Carolan, M., (2004). Ontological politics: mapping a complex environmental problem. Environmental Values, $13(4), 497-522$.

Chong, D \& Druckman, J. N. (2011). Identifying frames in political news. In E. P. Bucy, and R. L. Holbert (Eds.), The sourcebook for political communication research: Methods, measures, and analytical techniques (pp. 238-267). New York: Routledge.

Chong, D. \& Druckman, J. N. (2007). Framing public opinion in competitive democracies. American Political Science Review, 101, 637-655.

Corman, S., Brewer, G., Ball, H., Fisk, M., Fleischer, K., \&Ruston, S. (2013). A test of semantic text network validity using a false memory paradigm, XXXIII. Sunbelt Social Networks Conference of the International Network for Social Network Analysis (INSNA), May 21-26 2013, Hamburg, Germany.

Corner, A., Venables, D., Spence, A., Poortinga, W., Demski, C., \& Pidgeon, N. (2011). Nuclear power, climate change and energy security: Exploring British public attitudes. Energy Policy, 39, 4823-4833.

Creed, D., Langstraat, J., \& Scully, M. (2002). A picture of the frame: Frame analysis as technique and as politics. Organizational Research Methods January, 5(1), 34-55.

Daemen, T. J. (1993). The need for liability constraints in successful high-technology development: A comparison of the French and U.S. commercial nuclear programs. Northwestern Journal of 
International Law \& Business, 13(3), 684-710.

Danowski, J.A. (1993). Network analysis of message content. In G. Barnett, \& W. Richards (Eds.), Progress in communication sciences XII (pp. 197-22). Norwood, NJ: Ablex.

Danowski, J. A. (1982). Computer-mediated communication: A network based content analysis using a CBBS conference. In M. Burgoon (Ed.), Communication yearbook 6 (pp. 905-924). Beverly Hills, CA: Sage.

David, P. A., \& Rothwell, G. S. (1994). Measuring standardization: An application to the American and French nuclear power industries. European Journal of Political Economy, 12(Sept.), 291-308.

Dayton, D. (2000). Policy frames, policy making and the global climate change discourse. In H. Addams, \& J. Proops (Eds.), Social discourse and environmental policy: An application of $Q$ methodology (pp. 71-91). Edward Elgar, Cheltenham.

Delmas, M., \& Heiman, B. (2000).Government credible commitment to the French and American nuclear power industries. Journal of Policy Analysis and Management, 20(3), 433-456.

Derrida, J. (1978). Derrida: Writing and difference. Translated by A. Bass. London: Routledge \& Kegan Paul Ltd.

Diesner, J. (2012). Uncovering and managing the impact of methodological choices for the computational construction of socio-technical networks from texts. Ph.D. Dissertation, Carnegie Mellon University, Pittsburgh, PA.

Diesner, J., \& Carley, K. M. (2005). Revealing social structure from texts: Meta-matrix text analysis as a novel method for network text analysis. In V. K. Narayanan \& D. J. Armstrong (Eds.), Causal mapping for information systems and technology research: Approaches, advances, and illustrations (pp. 81-108). Harrisburg, PA: Idea Group Publishing.

Diesner, J. \& Carley, K. M. (2004). Using network text analysis to detect the organizational structure of covert networks. In Proceedings of the North American Association for Computational Social and Organizational Science (NAACSOS) Conference, Pittsburgh, PA. (July, 2004)

Doerfel, M. L. (1998). What constitutes semantic network analysis? A comparison of research and methodologies. Connections, 21(2), 16-26.

Doerfel, M., \& Barnett, G. (1999). A Semantic network analysis of the international communication association. Human Communication Research, 25(4), 589-603.

Doerfel, M. L. \& Connaughton, S. L. (2009). Semantic networks and competition: Election year winners and 
loses in U.S. televised presidential debates, 1960-2004. Journal of the American Society for Information Science and Technology, 60(1), 201-218.

Doerfel, M. L. \& Marsh, P. S. (2003).Candidate-issue positioning in the context of presidential debates. Journal of Applied Communication Research, 31(3), 212-237.

DTI. (2007). Energy white paper: Meeting the energy challenge. London: Department of Trade and Industry (DTI).

Dunn, W. N. (2003). Public policy analysis: An Introduction. Prentice Hall.

EIA. (2013). International energy outlook 2013. U.S. Energy Information Administration.

Entman, R. M. (1993). Framing: Toward clarification of a fractured paradigm. Journal of Communication, 43(4), 51-8.

Fischer, F. (2003). Reframing public policy: Discursive politics and deliberative practices. New York: Oxford University Press.

Fischer, F. \& Gottweis, H. (eds.). (2012). The argumentative turn revisited: Public policy as communication Practice. Durham, NC: Duke University Press.

Freeman, L. C. (1979). Centrality in social networks: Conceptual clarification. Social Networks, 1(3), $215-239$.

Gamson, W. A. (1992). The social psychology of collective action. In A. D. Morris \& C. M. Mueller (Eds.), Frontiers in Social Movement Theory (pp. 53-76). New Haven, CT: Yale University Press.

Gamson, W. A., \& Mogdiliani, A. (1989). Media discourse and public opinion on nuclear power: A constructionist approach. American Journal of Sociology, 95, 1-37.

Goffman, E. (1974). Frame Analysis: An essay on the organization of experience. New York, N.Y.: Harper \& Row.

Green, D. P., \& Shapiro, I. (1994). Pathologies of rational choice theory: A critique of applications in political science. Yale University Press.

Hajer, M. (1995). The politics of environmental discourse: Ecological modernization and the policy process. Clarendon Press, Oxford.

Hayashi, M., \& Hughes, L. (2013). The policy responses to the Fukushima nuclear accident and their effect on Japanese energy security. Energy Policy, 59(August), 86-101.

Hertog, J., \& McLeod, D. (2001). A Multiperspectival approach to framing Analysis: A field guide. In S. Reese, O. Gandy, \& A. Grant (Eds.), Framing public life (pp. 139-161). Mahwah, NJ: Erlbaum. 
HM Government. (2013). The UK's nuclear future. The UK government.

HM Government. (2008). Climate Change Bill. The UK government.

Hummon, N., \& Doreian, P. (1989). Connectivity in a citation network: The development of DNA theory. Social Networks, 11(1), 39-63.

IAEA. (2014). Nuclear safety and security. International Atomic Energy Agency. <http://www-ns.iaea.org/> IEE Japan. (2012). Energy security and challenges for Japan. Institute of Energy Economics.

Itoh, S. (2013). Energy security in Northeast Asia: A pivotal moment for the U.S.-Japan Alliance. Series:

Brookings East Asia Commentary

Iyengar, R. (1990). Shortcuts to political knowledge: The role of selective attention and accessibility. In J.

Ferejohn, \& J. Kuklinski (Eds.), Information and Democratic Processes (pp. 160-85). Champaign: University of Illinois Press.

Jang, H.-Y. \& Barnett, G. A. (1994). Cultural differences in organizational communication: A semantic network analysis. Bulletin of Methodological Sociology, 44, 31-59.

Joppke, C. (1991). Social movements during cycles of issue attention: The decline of the anti-nuclear energy movements in West Germany and the USA. British Journal of Sociology, 42(1), 43-60.

Kim, J. H., Su, T. Y. \& Hong, J. (2011). The influence of geopolitics and foreign policy on the U.S. and Canadian media: An analysis of newspaper coverage of Sudan's Darfur conflict. The Harvard International Journal of Press/Politics, 12(3), 87-95.

Krippendorff, K. (2004). Content analysis: An introduction to its methodology. Thousand Oaks, CA: Sage.

Kwon, K., Barnett, G. A. \& Chen, H. (2009). Assessing cultural differences in translations: A semantic network analysis of the universal declaration of human rights, Journal of International and Intercultural Communication, 2(2), 107-138.

Lakoff, G. (1996). Moral politics: what conservatives know that liberals don't. Chicago: University of Chicago Press.

Laws, D., \& Rein, M. (2003). Reframing practice. In M. Hajer, \& W. Hendrik (Eds.), Deliberative Policy Analysis: Understanding Governance in the Network Society (pp. 172-206). Cambridge University Press.

Lejano, P.L. (2006). Frameworks for policy analysis: Merging texts and contexts. New York: Routledge. Lewicki, R., Gray, B., \& Elliott, M. (2003). Making sense of intractable environmental conflicts: Concepts and 
cases, Washington, D.C.: Island Press.

Lukeš, D. (2007). Discourse-level constructions and frame analysis of policy discourse: Case of evaluation of university teaching. In: New Directions in Cognitive Linguistics 2007. Cardiff; 2007.

Majone, G. (1989). Evidence, argument \& persuasion in the policy process. New Haven, CT: Yale University Press.

Maynard, M. (1997). Opportunity in paid vs. unpaid public relations internships: A semantic network analysis. Public Relations Review, 23(4), 377-390.

Moody, J. (2004). The structure of a social science collaboration network: Disciplinary cohesion from 1963 to1999. American Sociological Review, 69(2), 213-238.

Nelson, T., Clawson, R. A., \& Oxley, Z. M. (1997). Media framing of a civil liberties conflict and its effect on tolerance. The American Political Science Review, 91(3), 567-583.

Newman, M. E. J. (2010). Networks: An introduction. New York: Oxford University Press.

Newman, M. E. J. (2006). Modularity and community structure in networks. PNAS, 103(23), 8577-8582.

Nohrstedt, D. (2005). External shocks and policy change: Three Mile Island and Swedish nuclear energy policy. Journal of European Public Policy, 12(6), 1041-1059.

Palfreman, J. (2009). Why the French like nuclear energy. PBS Frontline. Retrieved from <http://www.pbs.org/wgbh/pages/frontline/shows/reaction/readings/french.html>.

Paranyushkin, D. (2011). Identifying the pathways for meaning circulation using text network analysis. Published in December 11, 2011, Nodus Labs. Berlin Germany.

Paranyushkin, D. (2012). Visualization of text's polysingularity using network analysis. Published in January 15, 2011, Nodus Labs. Berlin Germany.

Pidgeon, N. F., Lorenzoni, I., \& Poortinga, W. (2008). Climate change or nuclear power-no thanks! a quantitative study of public perceptions and risk framing in Britain. Global Environmental Change, 18, $69-85$.

Popping, R. (2003). Knowledge graphs and network text analysis. Social Science Information, 42 (1), 91-106.

Popping, R. (2000). Computer-assisted text analysis. London, Thousand Oaks: Sage Publications.

Roberts, C. W. (1997). "Introduction." In C.W. Roberts (Ed.), Text analysis for the social sciences: Methods for Drawing Statistical Inferences from Texts and Transcripts (pp. 1-8). Mahwah, NJ: Lawrence Erlbaum Associates, Publishers. 
Rice, R. E. \& Danowski, J. A. (1993). Is it really just like a fancy answering machine? Comparing semantic networks of different types of voice mail users, The Journal of Business Communication, 30(4), 369397.

Saarikoski, H. (2006). When frames conflict: Policy dialogue on waste. Environment and Planning C: Government and Policy, 24, 615-630.

Salisbury, J. G. T. (2001). Using neural networks to assess corporate image. In M. West (Ed.), Progress in communication science, Vol. 17: Applications of Computer content analysis (pp. 65-86). Westport, CT: Ablex.

Sastry, R., \& Siegel, B. (2010). The French connection: Comparing French and American civilian nuclear energy programs. Stanford Journal of International Relations, Spring, 16-27.

Scheufele, D. A. (1999). Framing as a theory of media effects. Journal of Communication, 49(4), 103-22.

Schneider, M. et al. (2013). World nuclear industry status report 2013. Mycle Schneider Consulting Project.

Scholvin, S. (2014). South Africa's energy policy: Constrained by nature and path dependency, Journal of Southern African Studies, 40(1), 185-202.

Schön, D. A., \& Rein, M. (1994). Frame reflection: Toward the resolution of intractable policy controversies. New York: Basic Books.

Scott, J. (2000). Social network analysis: A handbook. $2^{\text {nd }}$ ed. Thousand Oaks, CA: Sage Publications Ltd.

Seoul Model United Nations XIV (2011). SEOMUN XIV Chair Research Report.

Semetko, H. A. \&Valkenburg, P. M. (2000). Framing European politics: A content analysis of press and television news, Journal of Communication, 50 (2), 93-109.

Sherblom, J.C. Reinsch, N. L. Jr, \& Beswick, R. W. (2001). Intersubjective semantic meanings emergent in a work group: A neural network content analysis of voice mail. In M. West (Ed.), Progress in communication science, Vol. 17: Applications of Computer content analysis (pp. 33-50). Westport, CT: Ablex.

Sirin, S. M. (2010). An assessment of Turkey's nuclear energy policy in light of South Korea's nuclear experience. Energy Policy, 38(10), 6145-6152.

Smith, A. E. \& Humphreys, M. S. (2006). Evaluation of unsupervised semantic mapping of natural language with Leximancer concept mapping. Behavioral Research Methods, 38(2): 262-279. 
Smith, A. E. (2003). Automatic extraction of semantic networks from text using Leximancer. In $H L T$-NAACL 2003 Human Language Technology Conference of the North American Chapter of the Association for Computational Linguistics: Companion volume (pp. Demo23-Demo24). Edmonton: ACL.

Sowa, J. F. (1992). Semantic networks. In S. C. Shapiro (Ed.), Encyclopedia of artificial intelligence. 2nd ed. (pp. 1493 - 1511). New York, NY: Wiley.

Srinivasan, T. N., \& Gopi Rethinaraj, T. S. (2013). Fukushima and thereafter: Reassessment of risks of nuclear power. Energy Policy, 52, 726-736.

Stokey, E., \& Zeckhauser, R. J. (1978). A primer for policy analysis. New York: Norton \& Company.

Stone, D. A. (1988). Policy paradox and political reason. HarperCollins Publishers.

Teräväinena, T., Lehtonenb, M., \& Martiskainen, M. (2011). Climate change, energy security, and riskdebating nuclear new build in Finland, France and the UK. Energy Policy, 39(6), 3434-3442.

The UK Government. (2013). Leading the way: the UK's new nuclear renaissance.

$<$ https://www.gov.uk/government/speeches/leading-the-way-the-uks-new-nuclear-renaissance >

Triandafyllidou A., \& Fotiou A. (1998). Sustainability and modernity in the European Union: a frame theory approach to policy-making. Sociological Research Online, 3(1).

$<$ http://www.socresonline.org.uk/3/1/2.html>

Toulmin, S., Rieke, R., \& Janik, A. (1984). An introduction to reasoning. $2^{\text {nd }}$ ed. New York: Macmillan Publishing Co., Inc.

UNFCC. (2014). Background on the UNFCCC: The international response to climate change, the United Nations Framework Convention on Climate Change (UNFCC). $<$ http://unfccc.int/essential_background/items/6031.php $>$

van Atteveldt, W., Kleinnijenhuis, J., \& Ruigrok, N. (2008). Parsing, semantic networks, and political authority using syntactic analysis to extract semantic relations from Dutch newspaper articles. Political Analysis, $16,428-446$.

van Dijk, T. A. (1977). Text and context. London: Longman.

van Eeten, M. M. J. (2007). Narrative policy analysis. In F. Fischer, G. J. Miller, \& M. S. Sidney (Eds.), Handbook of public policy analysis: Theory, politics, and methods (pp. 251-269). Boca Ranton, FI: CRD Press.

Vink, M.J., et al. (2012). Changing climate, changing frames. Environ. Sci. Policy. <http://dx.doi.org/ 10.1016/ 
j.envsci.2012.10.010>

Vivoda, V. (2012). Japan's energy security predicament post-Fukushima. Energy Policy, 46, 135-143.

Wasserman, S. \& Faust. K. (1994). Social network analysis: Methods and applications. New York: Cambridge University Press.

WEC. (2012). World energy perspective: Nuclear energy one year after Fukushima. World Energy Council.

Wilson Center. (2012). Going beyond nuclear: New energy security realities for Japan and the United States. <http://www.wilsoncenter.org/event/going-beyond-nuclear-new-energy-security-realities-forjapan-and-the-united-states>

WNA. (2014). Nuclear power in South Korea. World Nuclear Association<http://www.worldnuclear.org/info/Country-Profiles/Countries-O-S/South-Korea/>

WNA. (2014). US nuclear power policy. World Nuclear Association<http://www.worldnuclear.org/info/Country-Profiles/Countries-T-Z/USA--Nuclear-Power-Policy/> WNN. (2010). South Korea seeks to boost reactor exports. World Nuclear News. January, 13. 2010

Young, M. D. (1996). Cognitive Mapping Meets Semantic Networks. The Journal of Conflict Resolution, 40(3), 395-414 
Table 1: A Comparison of Quantitative and Qualitative Approaches to Frame Analysis

\begin{tabular}{l|l|l}
\hline & Quantitative Frame Analysis & Qualitative Frame Analysis \\
\hline Assumption & Frames are objectively identifiable & $\begin{array}{l}\text { Frames are embedded in text and may } \\
\text { change depending upon context }\end{array}$ \\
\hline $\begin{array}{l}\text { Coding } \\
\text { scheme }\end{array}$ & $\begin{array}{l}\text { - Developed prior to research: deductive } \\
\text { - Classification of keywords and terms as } \\
\text { indicators of a frame }\end{array}$ & $\begin{array}{l}\text { - Frames emerge during research: inductive } \\
\text { - Researcher's interpretive identification }\end{array}$ \\
\hline Coding & $\begin{array}{l}\text { - Objective: reliability and validity } \\
\text { - Utilization of content analysis software }\end{array}$ & $\begin{array}{l}\text { - Subjective: trustworthiness } \\
\text { - Inter-coder reliability }\end{array}$ \\
\hline Analysis & Statistical analysis: cluster analysis & $\begin{array}{l}\text { Discourse analysis: description of frame } \\
\text { characteristics }\end{array}$ \\
\hline
\end{tabular}


Table 2: Type of Concept by Degree and Betweenness Centrality

\begin{tabular}{|c|c|c|c|}
\hline & \multicolumn{2}{|l|}{ Betweenness } \\
\hline & & High & Low \\
\hline \multirow{2}{*}{ Degree } & High & Hub in the entire network: meaning circulation role & Local hub in community \\
\hline & Low & Bridging concept between local communities & Peripheral concepts \\
\hline
\end{tabular}


Table 3: Network Properties

\begin{tabular}{|l|l|l|l|l|l|l|l|}
\hline Characteristics & USA & UK & Germany & France & Japan & Korea & Integrated \\
\hline Nodes & 231 & 527 & 318 & 642 & 257 & 267 & 516 \\
\hline Ties & 331 & 914 & 507 & 1002 & 397 & 392 & 1770 \\
\hline Average degree & 2.87 & 3.47 & 3.19 & 3.12 & 3.09 & 2.94 & 6.86 \\
\hline Network diameter & 13 & 11 & 16 & 14 & 15 & 15 & 7 \\
\hline Average Path length & 4.886 & 4.117 & 5.683 & 5.267 & 4.548 & 4.672 & 3.146 \\
\hline Density & 0.012 & 0.007 & 0.010 & 0.005 & 0.012 & 0.011 & 0.013 \\
\hline Component & 2 & 1 & 4 & 2 & 1 & 1 & 1 \\
\hline $\begin{array}{l}\text { Degree centralization } \\
\text { index }\end{array}$ & $2.01 \%$ & $1.92 \%$ & $2.04 \%$ & $1.67 \%$ & $1.92 \%$ & $1.53 \%$ & $1.17 \%$ \\
\hline $\begin{array}{l}\text { Betweenness } \\
\text { centralization index }\end{array}$ & $47.24 \%$ & $31.43 \%$ & $51.52 \%$ & $20.97 \%$ & $35.38 \%$ & $38.96 \%$ & $27.63 \%$ \\
\hline $\begin{array}{l}\text { Modularity (total \# of } \\
\text { community) }\end{array}$ & $0.628(18)$ & $0.572(19)$ & $0.684(26)$ & $0.651(20)$ & $0.621(15)$ & $0.618(13)$ & $0.403(12)$ \\
\hline $\begin{array}{l}\text { Nodes of } 1^{\text {st }} \text { largest } \\
\text { community (\% of nodes) }\end{array}$ & $32(13.9 \%)$ & $55(10.4 \%)$ & $38(11.9 \%)$ & $61(9.5 \%)$ & $31(12.1 \%)$ & $39(14.6 \%)$ & $92(17.8 \%)$ \\
\hline $\begin{array}{l}\text { Nodes of } 2^{\text {nd }} \text { largest } \\
\text { community (\% of nodes) }\end{array}$ & $27(11.7 \%)$ & $49(9.3 \%)$ & $33(10.4 \%)$ & $51(7.9 \%)$ & $28(10.9 \%)$ & $30(11.2 \%)$ & $84(16.3 \%)$ \\
\hline $\begin{array}{l}\text { Nodes of 3 } 3^{\text {rd }} \text { largest } \\
\text { community (\% of nodes) }\end{array}$ & $23(10.0 \%)$ & $47(8.9 \%)$ & $31(9.7 \%)$ & $43(6.7 \%)$ & $23(8.9 \%)$ & $23(8.6 \%)$ & $57(11.0 \%)$ \\
\hline
\end{tabular}

* Unit is the number of words. 
Table 4: Influential Concepts in the Four Largest Communities of the Six Countries

\begin{tabular}{|c|c|c|c|c|c|c|}
\hline \multicolumn{2}{|c|}{ Community USA } & \multirow[b]{2}{*}{\begin{tabular}{|l} 
UK \\
UK, New, \\
Nuclear, Energy, \\
Market, Build, \\
Economy, Time, \\
Project
\end{tabular}} & \multirow[b]{2}{*}{\begin{tabular}{|l} 
Germany \\
Nuclear, Renewable, \\
Energy, Technology, \\
Germany, Will, Invest, \\
Future, Consensus
\end{tabular}} & \multirow[b]{2}{*}{\begin{tabular}{|l|} 
France \\
Nuclear, Energy, \\
Risk, Security, \\
Supply, Interest, \\
Choice, Industry, \\
Sector \\
\end{tabular}} & \multirow[b]{2}{*}{\begin{tabular}{|l} 
Japan \\
Japan, Will, \\
Expectation, Year, \\
Responsibility, \\
Fundamental, \\
Decision \\
\end{tabular}} & \multirow[b]{2}{*}{\begin{tabular}{|l|} 
Korea \\
Energy, Alternative, \\
Growth, \\
Contribute_to, \\
Independence, \\
Demand \\
\end{tabular}} \\
\hline $\begin{array}{l}1^{\text {st }} \text { largest } \\
\text { community }\end{array}$ & $\begin{array}{l}\text { Nuclear, Energy, } \\
\text { Clean, Electricity, } \\
\text { Generation, } \\
\text { Source, Have_been }\end{array}$ & & & & & \\
\hline $\begin{array}{l}2^{\text {nd }} l a \\
\text { comn }\end{array}$ & $\begin{array}{l}\text { an, } \mathrm{U} \\
\text { Com } \\
\text { Civil }\end{array}$ & $\begin{array}{l}\text { Will, Government, } \\
\text { Renewable, Coal, } \\
\text { Nuclear, Industry }\end{array}$ & $\begin{array}{l}\text { Nuclear_power_plant, } \\
\text { Expiration, } \\
\text { Decision,Time, Extend, } \\
\text { Plan }\end{array}$ & $\begin{array}{l}\text { e, Electricity, } \\
\text { my, Country, } \\
\text { etitiveness, } \\
\text { Level, ASN }\end{array}$ & $\begin{array}{l}\mathrm{Co} \\
\mathrm{Co} \\
\mathrm{Re}\end{array}$ & $\begin{array}{l}\text { Nuc } \\
\text { Glo } \\
\text { Effo }\end{array}$ \\
\hline $\begin{array}{l}3^{\text {rd }} \text { largest } \\
\text { community }\end{array}$ & $\begin{array}{l}\text { Clim } \\
\text { Cont } \\
\text { Futu }\end{array}$ & $\begin{array}{l}\text { Business, Plan, } \\
\text { Global, Interest, } \\
\text { Recognize, } \\
\text { Opportunity } \\
\end{array}$ & $\mathrm{y}$ & $\begin{array}{l}\text { Future } \\
\text { Econo } \\
\text { Issue }\end{array}$ & $\begin{array}{l}\text { _power, } \\
\text { Policy, } \\
\text {, Promote, } \\
\text { ion }\end{array}$ & $\begin{array}{l}\text { Will, } \\
\text { dence, IAEA, } \\
\text { ful, Use }\end{array}$ \\
\hline $\begin{array}{l}4^{\text {th }} \text { largest } \\
\text { community }\end{array}$ & $\begin{array}{l}\text { Safety, Power, } \\
\text { Ensure, Industry, } \\
\text { Build (20) }\end{array}$ & $\begin{array}{l}\text { Oversea, } \\
\text { Investment, } \\
\text { Country, Potential, } \\
\text { International, } \\
\text { Enhancement (39) }\end{array}$ & $\begin{array}{l}\text { Nuclear_power, } \\
\text { Electricity, Generation, } \\
\text { Supply (27) }\end{array}$ & $\begin{array}{l}\text { International, } \\
\text { Cooperation, } \\
\text { Regulatory, Standar } \\
(37)\end{array}$ & $\begin{array}{l}\text { Safety, New, } \\
\text { Standard, Reform, } \\
\text { Plant, Policy (20) }\end{array}$ & $\begin{array}{l}\text { Public, } \\
\text { Understanding, } \\
\text { Communication (22) }\end{array}$ \\
\hline
\end{tabular}

* Bold indicates top ranking concepts both in degree and betweenness centrality, which means that these words play a meaning circulation role in concept networks of each country.

** Parentheses indicate the number of concepts in a community. 
Table 5: Comparisons of Influential Concepts before and after the Fukushima Accident for Four Countries

\begin{tabular}{|l|l|l|l|}
\hline Country & Same & More Influential Before & More Influential After \\
\hline Germany & $\begin{array}{l}\text { Energy, Nuclear_power, } \\
\text { Renewable }\end{array}$ & Scenario, Bridge, Difference, Will & $\begin{array}{l}\text { Consensus, Extension, Issue, } \\
\text { Disaster, Have-been }\end{array}$ \\
\hline UK & Nuclear, Industry & $\begin{array}{l}\text { Carbon, Investment, Role, } \\
\text { Decommission, Emission, Waste }\end{array}$ & $\begin{array}{l}\text { New, Build, Opportunity, } \\
\text { Government, Benefit, Business }\end{array}$ \\
\hline Japan & Nuclear, Cooperation, & $\begin{array}{l}\text { International_community, } \\
\text { Continue, Lead_to, Reduction, } \\
\text { Advance }\end{array}$ & $\begin{array}{l}\text { Safety, Fundamental, Reform, } \\
\text { Electricity, Contribute_to, Market }\end{array}$ \\
\hline USA & $\begin{array}{l}\text { Nuclear, Energy, Clean, } \\
\text { Plant, Safety }\end{array}$ & Expert, Investment, Finance, Job & $\begin{array}{l}\text { Climate, Change, Commitment, } \\
\text { Contribute_to, Demand }\end{array}$ \\
\hline
\end{tabular}


Table 6: The Top 30 Ranking Concepts by Degree and Betweenness Centrality (Integrated Network)

\begin{tabular}{|c|c|c|c|c|}
\hline \multirow{2}{*}{ Rank } & \multicolumn{2}{|c|}{ After the Fukushima accident } & \multicolumn{2}{|c|}{ Before the Fukushima accident } \\
\hline & Betweenness centrality & Degree centrality & Betweenness centrality & Degree centrality \\
\hline 1 & Nuclear & Nuclear* & Nuclear & Nuclear* \\
\hline 2 & Energy & Energy* & Energy & Energy* \\
\hline 3 & Will & Safety* & Will & Will* \\
\hline 4 & Safety & Will* & Nuclear power & Nuclear_power* \\
\hline 5 & Nuclear-power-plant & New & Japan & Japan* \\
\hline 6 & Japan & Nuclear-power-plant & Investment & Investment* \\
\hline 7 & UK & Japan & Carbon & Carbon* \\
\hline 8 & New & Investment & Security & Security* \\
\hline 9 & Investment & Nuclear-power & Level** $^{* *}$ & Role*** \\
\hline 10 & Nuclear-power & Government & Industry & Ensure*** \\
\hline 11 & Country & UK & Renewable & Industry \\
\hline 12 & Government & Country & Waste & Generation*** \\
\hline 13 & Electricity & Electricity & Emission** & Renewable \\
\hline 14 & Issue $* *$ & Industry*** & Role & Power \\
\hline 15 & have-been & Build*** & Manage & Level \\
\hline 16 & Plan** & have-been & Ensure & Low*** \\
\hline 17 & Challenge & Challenge & Clean*** & Sector \\
\hline 18 & Renewable** & Decision & Plan** & Waste \\
\hline 19 & Year & France & Generation & Manage \\
\hline 20 & Decision & Continue $* * *$ & Include & New*** \\
\hline 21 & Sector & Sector & Power & Emission \\
\hline 22 & Security** & Technology**** & Plant** & Cooperation*** \\
\hline 23 & Time & Global & Progress & Include \\
\hline 24 & Economy** & Enhancement & Mutual & Operation \\
\hline 25 & France & Provide & Increase & Plan \\
\hline 26 & Global & Plant & Protection & UK \\
\hline 27 & Build & Generation & Fuel & Bridge \\
\hline 28 & Needs & Security & New & Peaceful \\
\hline 29 & Technology & Renewable & Company & Technology \\
\hline 30 & Industry & Plan & Environment & Use \\
\hline
\end{tabular}

*: Hub, meaning circulation

**: Bridging between communities

***: Local center (local hub) 
Table 7: Influential Concepts in the Local Communities (Integrated Network)

\begin{tabular}{|c|c|}
\hline Community & Influential concepts \\
\hline Community 1(92) & $\begin{array}{l}\text { nuclear UK new sector security build industry programme interest international plant } \\
\text { use enhancement supply continue take_place remain }\end{array}$ \\
\hline Community 2(84) & $\begin{array}{l}\text { way better goal people will country provide benefits progress improvement capability } \\
\text { area meet economy }\end{array}$ \\
\hline Community 3(57) & $\begin{array}{l}\text { energy investment nuclear_power electricity ensure generation develop potential policy } \\
\text { safe clean source considerable secure business system have_been }\end{array}$ \\
\hline Community 4(42) & $\begin{array}{l}\text { Japan nuclear_power_plant decommission time Fukushima extension accident restart } \\
\text { expiration area lesson position responsibility best share protection }\end{array}$ \\
\hline Community 5(37) & needs consideration prospect talk to problems serious increase focus \\
\hline Community 6(32) & fossil fuels limitation exit support implementation conclusion carbon \\
\hline Community $7(27)$ & question climate effort contribute to change launch today enhance strong mitigation \\
\hline Community $8(25)$ & public understanding communication danger Korea review peaceful seek \\
\hline Community 9(24) & $\begin{array}{l}\text { market private_sector US government plan commit long-term promote high citizen } \\
\text { choice consistently greatest advance }\end{array}$ \\
\hline Community 10(24) & $\begin{array}{l}\text { global opportunity economic work oversea job discussion growth consider } \\
\text { management improve fundamental }\end{array}$ \\
\hline Community 11(23) & $\begin{array}{l}\text { risk reduce Germany decision global coal gas power_plant } \mathrm{CO}_{2} \text { emission renewable } \\
\text { consensus information level community }\end{array}$ \\
\hline Community 12 (19) & $\begin{array}{l}\text { safety IAEA standard strengthen regulatory progress disaster world cooperation } \\
\text { commitment }\end{array}$ \\
\hline Community 13(16) & $\begin{array}{l}\text { force technology operators } \mathrm{ASN}^{* *} \text { help facility material assessment policy } \\
\text { independence audit training element recommendation skill response }\end{array}$ \\
\hline Community 14 (14) & France cost control challenge material future issue reason price objective measure \\
\hline
\end{tabular}


Table 8: Similarities between the Integrated and Individual networks (after the Fukushima accident)

\begin{tabular}{|c|c|c|c|c|c|c|c|}
\hline Policy Frames & Policy arguments from communities & USA & UK & Germany & France & Japan & Korea \\
\hline \multirow{3}{*}{$\begin{array}{l}\text { Energy security } \\
\text { frame: Meeting } \\
\text { the growing } \\
\text { energy needs }\end{array}$} & $\begin{array}{l}\text { Progress in this area to meet these goals will } \\
\text { improve capability and be a better way to } \\
\text { provide benefits for the economy, country and } \\
\text { people }\end{array}$ & $\bigcirc$ & & & $\triangle$ & $\bigcirc$ & $\triangle$ \\
\hline & $\begin{array}{l}\text { Sharing lessons from the Fukushima accident } \\
\text { in Japan, it is time to decommission the } \\
\text { expired and this is the best position to restart } \\
\text { and extend, there is a responsibility to protect } \\
\text { nuclear power plants in the area }\end{array}$ & & & & $\triangle$ & $\bigcirc$ & \\
\hline & $\begin{array}{l}\text { Serious talk about problems can increase } \\
\text { consideration of needs and focus on prospects }\end{array}$ & & $\triangle$ & $\triangle$ & $\triangle$ & $\triangle$ & $\triangle$ \\
\hline \multirow{4}{*}{$\begin{array}{l}\text { Clean energy } \\
\text { frame: } \\
\text { Contributing to } \\
\text { the mitigation } \\
\text { of climate } \\
\text { change }\end{array}$} & $\begin{array}{l}\text { The policy is to secure considerable } \\
\text { investment from business to develop nuclear } \\
\text { power systems with the potential to ensure } \\
\text { clean and safe electricity generation as an } \\
\text { energy resource }\end{array}$ & $\bigcirc$ & $\triangle$ & & & & $\triangle$ \\
\hline & $\begin{array}{l}\text { The conclusion is that there are limitations to } \\
\text { fossil and carbon fuels and we support the } \\
\text { implementation of an exit }\end{array}$ & & & $\bigcirc$ & & & \\
\hline & $\begin{array}{l}\text { Today we launch strong efforts to enhance } \\
\text { our contribution to the question of how to } \\
\text { mitigate climate change }\end{array}$ & & $\triangle$ & $\triangle$ & & & \\
\hline & $\begin{array}{l}\text { There is a community consensus on } \\
\text { renewables and a decision to reduce the level } \\
\text { of risk from coal and gas power_plants and } \\
\mathrm{CO}_{2} \text { emissions }\end{array}$ & & $\triangle$ & $\bigcirc$ & & & \\
\hline \multirow{4}{*}{$\begin{array}{l}\text { Economic } \\
\text { growth frame: } \\
\text { Sustaining } \\
\text { economic } \\
\text { development }\end{array}$} & $\begin{array}{l}\text { The UK remains interested in continuing the } \\
\text { programme to build and use new plants to } \\
\text { enhance the sector and industry and supply } \\
\text { nuclear security }\end{array}$ & & $\bigcirc$ & & & & \\
\hline & $\begin{array}{l}\text { The government choice is to plan to promote } \\
\text { the greatest private sector commitment and to } \\
\text { consistently advance the market over the } \\
\text { long-term for citizens }\end{array}$ & $\triangle$ & $\triangle$ & & $\triangle$ & & \\
\hline & $\begin{array}{l}\text { Fundamentally, this is a global opportunity } \\
\text { for discussions to consider management and } \\
\text { how to improve economic growth, work and } \\
\text { jobs }\end{array}$ & & $\triangle$ & & $\triangle$ & & $\triangle$ \\
\hline & $\begin{array}{l}\text { In France the challenge and objective is to } \\
\text { control the material price issue for future cost } \\
\text { measure reasons }\end{array}$ & & & & $\bigcirc$ & & \\
\hline \multirow{3}{*}{$\begin{array}{l}\text { Nuclear safety } \\
\text { frame: } \\
\text { Reducing } \\
\text { public } \\
\text { opposition to } \\
\text { nuclear power. }\end{array}$} & $\begin{array}{l}\text { We seek public understanding through } \\
\text { reviewing and communicating the dangers } \\
\text { and peaceful uses }\end{array}$ & & & & & $\bigcirc$ & $\triangle$ \\
\hline & $\begin{array}{l}\text { An element of the policy response is to } \\
\text { recommend independent assessment and } \\
\text { audit of facilities and help with technology } \\
\text { and training of skilled operators }\end{array}$ & $\triangle$ & & & & $\triangle$ & $\triangle$ \\
\hline & $\begin{array}{l}\text { The disaster strengthened progress in IAEA } \\
\text { and world cooperation as well as commitment } \\
\text { to regulatory and safety standards }\end{array}$ & & & & & $\triangle$ & $\triangle$ \\
\hline
\end{tabular}

$\bigcirc$ : The policy frame is almost the same.

$\triangle$ : The policy frame is similar. 
Table 8-1: Similarities between the Integrated and Individual networks (prior to the Fukushima Accident)

\begin{tabular}{|c|c|c|c|c|c|}
\hline Policy Frames & Policy arguments from communities & USA & UK & Germany & Japan \\
\hline \multirow{2}{*}{$\begin{array}{l}\text { Energy security } \\
\text { frame }\end{array}$} & $\begin{array}{l}\text { The plan is to use nuclear and renewables to } \\
\text { forward manage energy supplies. }\end{array}$ & $\triangle$ & & & $\triangle$ \\
\hline & $\begin{array}{l}\text { Important role of companies in promoting energy } \\
\text { security needs to be built. }\end{array}$ & & $\triangle$ & & \\
\hline \multirow{3}{*}{$\begin{array}{l}\text { Clean energy } \\
\text { frame }\end{array}$} & $\begin{array}{l}\text { So far, regulation has achieved percentage } \\
\text { reductions and changed electricity generation for } \\
\text { our shared environment goals. }\end{array}$ & & & $\triangle$ & $\triangle$ \\
\hline & $\begin{array}{l}\text { Maintain progress and increase confidence about } \\
\text { future scenarios and establishing emission level. }\end{array}$ & & $\triangle$ & $\triangle$ & $\triangle$ \\
\hline & $\begin{array}{l}\text { Consideration for the dependence on fossil fuels } \\
\text { should be limited }\end{array}$ & $\triangle$ & $\triangle$ & & \\
\hline \multirow{3}{*}{$\begin{array}{l}\text { Economic } \\
\text { growth frame }\end{array}$} & $\begin{array}{l}\text { Ensure investment for industry to deliver on its } \\
\text { commitment to appropriate reactor construction } \\
\text { and design and efforts to provide skills for the } \\
\text { operator workforce. }\end{array}$ & & $\triangle$ & & \\
\hline & $\begin{array}{l}\text { We will challenge the private sector to drive } \\
\text { advances and capacity extension in the long-term. }\end{array}$ & & ○ & & O \\
\hline & $\begin{array}{l}\text { The low carbon sector has potential including low } \\
\text { prices and job creation but continues to face } \\
\text { strong barriers. }\end{array}$ & $\triangle$ & $\triangle$ & & \\
\hline \multirow{3}{*}{$\begin{array}{l}\text { Nuclear safety } \\
\text { frame }\end{array}$} & $\begin{array}{l}\text { Mutual respect and cooperation can lead to } \\
\text { agreement on the matter of safeguarding materials } \\
\text { and growth in this area. }\end{array}$ & & & & $\bigcirc$ \\
\hline & $\begin{array}{l}\text { The government has long decided to use } \\
\text { technology for peaceful nuclear power plants for } \\
\text { the public. }\end{array}$ & & & & $\bigcirc$ \\
\hline & $\begin{array}{l}\text { Protection through decommissioning radioactive } \\
\text { waste disposal operations has costs. }\end{array}$ & & $\triangle$ & & \\
\hline
\end{tabular}

$\bigcirc$ : The policy frame is almost the same.

$\triangle$ : The policy frame is similar. 
Appendix 1: Comparison of Nuclear Energy among Six Countries

\begin{tabular}{|c|c|c|c|c|c|c|c|c|c|c|}
\hline \multirow{3}{*}{\begin{tabular}{|l} 
Country \\
Unit
\end{tabular}} & \multirow{2}{*}{\multicolumn{2}{|c|}{$\begin{array}{l}\text { Nuclear } \\
\text { Electricity } \\
\text { Generation } 2012\end{array}$}} & \multicolumn{2}{|c|}{$\begin{array}{l}\text { Reactors } \\
\text { Operable }\end{array}$} & \multicolumn{2}{|c|}{$\begin{array}{l}\text { Reactors Under } \\
\text { Construction }\end{array}$} & \multicolumn{2}{|c|}{$\begin{array}{l}\text { Reactors } \\
\text { Planned }\end{array}$} & \multicolumn{2}{|c|}{$\begin{array}{l}\text { Reactors } \\
\text { Proposed }\end{array}$} \\
\hline & & & \multicolumn{2}{|c|}{ Oct. 2013} & \multicolumn{2}{|c|}{ Oct. 2013} & \multicolumn{2}{|c|}{ Oct. 2013} & \multicolumn{2}{|c|}{ Oct. 2013} \\
\hline & $\begin{array}{l}\text { billion } \\
\mathrm{kWh}\end{array}$ & $\% \mathrm{e}$ & No. & MWe net & No. & $\begin{array}{l}\text { MWe } \\
\text { gross }\end{array}$ & No. & $\begin{array}{l}\text { MWe } \\
\text { gross }\end{array}$ & No. & $\begin{array}{l}\text { MWe } \\
\text { gross }\end{array}$ \\
\hline France & 407.4 & 74.8 & 58 & 63130 & 1 & 1720 & 1 & 1720 & 1 & 1100 \\
\hline Germany & 94.1 & 16.1 & 9 & 12003 & 0 & 0 & 0 & 0 & 0 & 0 \\
\hline Japan & 17.2 & 2.1 & 50 & 44396 & 3 & 3036 & 9 & 12947 & 3 & 4145 \\
\hline Korea & 143.5 & 30.4 & 23 & 20787 & 5 & 6870 & 6 & 8730 & 0 & 0 \\
\hline UK & 64 & 18.1 & 16 & 10038 & 0 & 0 & 4 & 6680 & 9 & 12000 \\
\hline USA & 770.7 & 19 & 100 & 98951 & 3 & 3618 & 9 & 10860 & 15 & 24000 \\
\hline World & 2346 & 11 & 432 & 371,900 & 70 & 73,366 & 173 & 187,740 & 314 & 356,986 \\
\hline
\end{tabular}

* Source: World Nuclear Association (2013)

Appendix 2: Network Properties: prior to the Fukushima Accident

\begin{tabular}{|l|l|l|l|l|l|}
\hline Characteristics & USA & UK & Germany & Japan & Integrated \\
\hline Nodes & 220 & 240 & 170 & 192 & 249 \\
\hline Ties & 310 & 357 & 221 & 265 & 761 \\
\hline Average degree & 2.82 & 3.06 & 2.6 & 2.76 & 6.11 \\
\hline Network diameter & 12 & 11 & 17 & 15 & 6 \\
\hline Average Path length & 4.58 & 4.478 & 5.341 & 5.092 & 2.941 \\
\hline Density & 0.013 & 0.013 & 0.015 & 0.014 & 0.025 \\
\hline Component & 2 & 2 & 1 & 2 & 1 \\
\hline $\begin{array}{l}\text { Degree centralization } \\
\text { index }\end{array}$ & $1.78 \%$ & $2.16 \%$ & $2.54 \%$ & $2.96 \%$ & $2.13 \%$ \\
\hline $\begin{array}{l}\text { Betweenness } \\
\text { centralization index }\end{array}$ & $46.57 \%$ & $36.88 \%$ & $50.61 \%$ & $39.23 \%$ & $26.51 \%$ \\
\hline $\begin{array}{l}\text { Modularity (total \# of } \\
\text { community) }\end{array}$ & $0.648(18)$ & $0.629(14)$ & $0.650(12)$ & $0.688(13)$ & $0.412(12)$ \\
\hline $\begin{array}{l}\text { Nodes of 1st largest } \\
\text { community (\% of nodes) }\end{array}$ & $30(13.6 \%)$ & $30(12.5 \%)$ & $31(18.2 \%)$ & $22(11.5 \%)$ & $41(16.5 \%)$ \\
\hline $\begin{array}{l}\text { Nodes of } 2^{\text {nd }} \text { largest } \\
\text { community (\% of nodes) }\end{array}$ & $30(13.6 \%)$ & $29(12.1 \%)$ & $29(17.1 \%)$ & $20(10.4 \%)$ & $34(13.7 \%)$ \\
\hline $\begin{array}{l}\text { Nodes of 3d largest } \\
\text { community (\% of nodes) }\end{array}$ & $22(10.0 \%)$ & $25(10.4 \%)$ & $23(13.5 \%)$ & $19(9.9 \%)$ & $28(11.2 \%)$ \\
\hline
\end{tabular}

* Unit is the number of words. 
Appendix 3: Influential Concepts in the Four Largest Communities of the Four Countries: prior to the Fukushima Accident

\begin{tabular}{|c|c|c|c|c|}
\hline Community & USA & UK & Germany & Japan \\
\hline $\begin{array}{l}1^{\text {st }} \text { largest } \\
\text { community }\end{array}$ & $\begin{array}{l}\text { Nuclear, Energy, Source, } \\
\text { Fuel, Expert, Leader, } \\
\text { Grow, Industry (30) }\end{array}$ & $\begin{array}{l}\text { Energy, Challenge, } \\
\text { Potential, Supply, Fuel, } \\
\text { Create, Company, Relieve } \\
(30)\end{array}$ & $\begin{array}{l}\text { Will, Significantly, } \\
\text { Expand, Current, Network, } \\
\text { Talk_to, Extension, } \\
\text { Context, Plan, Decide (31) }\end{array}$ & $\begin{array}{l}\text { Nuclear, Energy, Security, } \\
\text { Material, Strengthen, } \\
\text { Commitment, Sign, } \\
\text { Around_the_world (22) }\end{array}$ \\
\hline $\mid \begin{array}{l}2^{\text {nd }} \text { largest } \\
\text { community }\end{array}$ & $\begin{array}{l}\text { Plant, Nuclear_power, } \\
\text { Will, Year, Generate, Job, } \\
\text { Create, Country, Coal, } \\
\text { Continue (30) }\end{array}$ & $\begin{array}{l}\text { Nuclear, Industry, } \\
\text { Investment, New, Build, } \\
\text { Manage, Capacity, Policy, } \\
\text { Willing_to (29) }\end{array}$ & $\begin{array}{l}\text { Energy, Renewable, } \\
\text { Achieve, Reach, Nuclear, } \\
\text { Age, Quickly, Promote, } \\
\text { Policy, Promote (29) }\end{array}$ & $\begin{array}{l}\text { Level, Emission, Station, } \\
\text { Maintain, Actual, Foresee, } \\
\text { Biggest, Establish, CO2 } \\
(20)\end{array}$ \\
\hline $\mid \begin{array}{l}3^{\text {rd }} \text { largest } \\
\text { community }\end{array}$ & $\begin{array}{l}\text { Clean, Nautral_gas, safety, } \\
\text { Finance, Provide, Reserve, } \\
\text { transition, Provide (22) }\end{array}$ & $\begin{array}{l}\text { Nuclear_power, Role, } \\
\text { Provide, Certainty, Clear, } \\
\text { Importance, Coalition, } \\
\text { Reduction }(25)\end{array}$ & $\begin{array}{l}\text { Bridge, Technology, Time, } \\
\text { Share, Environment, } \\
\text { Realistic, Electricity, } \\
\text { Today (23) }\end{array}$ & $\begin{array}{l}\text { Cooperation, Area, } \\
\text { Mutual, Agreement, } \\
\text { Matter, Importance, } \\
\text { Assistance, Strategy, } \\
\text { Beneficial (19) }\end{array}$ \\
\hline $\mid \begin{array}{l}4^{\text {th }} \text { largest } \\
\text { community }\end{array}$ & $\begin{array}{l}\text { Investment, Oil, Area, } \\
\text { Break, Tax, Prioritize, } \\
\text { Company, Decision (19) }\end{array}$ & $\begin{array}{l}\text { Low, Carbon, Emission, } \\
\text { Economy, Lower, Price, } \\
\text { Society, Infrastructure, } \\
\text { Control (23) }\end{array}$ & $\begin{array}{l}\text { Scenario, Difference, Fact, } \\
\text { Lead_to, Calculate, Table, } \\
\text { Discussion, Solar, Concern } \\
\text { (23) }\end{array}$ & $\begin{array}{l}\text { Will, Advance, } \\
\text { Private_sector, Target, } \\
\text { Effort, Attain, Combine, } \\
\text { Development (17) }\end{array}$ \\
\hline $\begin{array}{l}\text { Other key } \\
\text { community }\end{array}$ & $\begin{array}{l}\text { Gas, Legitimate, Change, } \\
\text { Greenhouse, Climate, } \\
\text { Prevent (14) }\end{array}$ & $\begin{array}{l}\text { Waste, Decommission, } \\
\text { Long_term, Cost, Activity, } \\
\text { Disposal, Operation, } \\
\text { Radioactive, Essential (21) }\end{array}$ & $\begin{array}{l}\text { Nuclear_power, Plant, } \\
\text { Germany, Operation, } \\
\text { Call_for, Clear, } \\
\text { Replacement (19) }\end{array}$ & $\begin{array}{l}\text { Peaceful, Use, } \\
\text { Nuclear_power } \\
\text { Technology, Guarantee, } \\
\text { Plant (13) }\end{array}$ \\
\hline
\end{tabular}

* Parentheses indicate the number of concepts in a community.

\section{Appendix 4: Example of Coding}

Original text (a sentence): Whilst nuclear energy has the advantages of being an inexpensive and clean energy source, it is with greater confidence in its safety that it can be more widely used.

Converted to: nuclear energy advantage inexpensive clean energy source greater confidence safety widely use

Each word is defined as a node. Then, two consecutive words are connected; nuclear-energy, energy-advantage, advantage-inexpensive.... safety-widely, widely-use. 
Appendix 5: Data Collection for Semantic Network Analysis by the Six Countries

\begin{tabular}{|c|c|c|c|c|c|}
\hline Country & $\begin{array}{l}\text { No. of } \\
\text { text used }\end{array}$ & $\begin{array}{l}\text { Language } \\
\text { provided }\end{array}$ & By whom & Excerpts from & Source (Website) \\
\hline \multirow[b]{2}{*}{ USA } & 6 (before) & \multirow[b]{2}{*}{ English } & $\begin{array}{l}\text { President (Barack } \\
\text { Obama) }\end{array}$ & $\begin{array}{l}6 \text { remarks by the President (16 } \\
\text { Feb., } 31 \text { March, } 2 \text { April, } 2 \\
\text { June, } 6 \text { Sept., } 25 \text { Oct. } 2010 \text { ) }\end{array}$ & \multirow[t]{2}{*}{$\underline{\text { www.whitehouse.gov }}$} \\
\hline & 7 (after) & & $\begin{array}{l}\text { President (Barack } \\
\text { Obama) }\end{array}$ & $\begin{array}{l}7 \text { remarks by the President (17 } \\
\text { March, } 30 \text { March 2011, } 23 \\
\text { Feb., } 7 \text { March } 22 \text { March, 26 } \\
\text { March 2012, } 15 \text { March 2013) }\end{array}$ & \\
\hline \multirow{2}{*}{ UK } & 6 (before) & \multirow{2}{*}{ English } & $\begin{array}{l}\text { Minister of State for } \\
\text { Energy (Charles } \\
\text { Hendry) and } \\
\text { Secretary (Chris } \\
\text { Huhne) }\end{array}$ & $\begin{array}{l}4 \text { Ministerial speeches (16 } \\
\text { June, } 21 \text { Oct. 2010, and } 31 \\
\text { Jan, } 2 \text { March 2011) and } 2 \\
\text { Secretary speeches (16 Dec. } \\
\text { 2010, } 24 \text { Jan. 2011) }\end{array}$ & \multirow[t]{2}{*}{$\begin{array}{l}\text { https://www.gov.uk/go } \\
\text { vernment/organisations } \\
\text { /cabinet-office }\end{array}$} \\
\hline & 3 (after) & & $\begin{array}{l}\text { Prime Minister } \\
\text { (David Cameron) and } \\
\text { Minister of State for } \\
\text { Energy (Michael } \\
\text { Fallon) }\end{array}$ & $\begin{array}{l}1 \text { Ministerial speech (17 Sept. } \\
\text { 2013) and } 2 \text { Prime Ministerial } \\
\text { addresses (26 April } 2012 \text { and } \\
19 \text { March 2012) }\end{array}$ & \\
\hline \multirow{2}{*}{ Germany } & 5 (before) & \multirow{2}{*}{$\begin{array}{l}\text { German } \\
\text { (translated } \\
\text { to English) }\end{array}$} & $\begin{array}{l}\text { Prime Minister } \\
\text { (Angela Merkel) }\end{array}$ & $\begin{array}{l}5 \text { Prime Ministerial interviews } \\
\text { (25 Feb., } 13 \text { June, and } 7 \text { July, } \\
29 \text { Sept., } 8 \text { Nov., 2010, ) }\end{array}$ & \multirow{2}{*}{$\begin{array}{l}\frac{\text { http://www.bundeskanz }}{\text { lerin.de/Webs/BKin/DE }} \\
\underline{\text { Startseite/startseite no }} \\
\underline{\text { de.html }}\end{array}$} \\
\hline & 2 (after) & & $\begin{array}{l}\text { Prime Minister } \\
\text { (Angela Merkel) }\end{array}$ & $\begin{array}{l}1 \text { Prime Ministerial speech (15 } \\
\text { April 2011) and } 1 \text { interview } \\
(12 \text { May 2011) }\end{array}$ & \\
\hline France & 4 & $\begin{array}{l}\text { French } \\
\text { (translated } \\
\text { to English) }\end{array}$ & $\begin{array}{l}\text { Prime Minister } \\
\text { (François Fillon) and } \\
\text { President (François } \\
\text { Hollande) }\end{array}$ & $\begin{array}{l}1 \text { Prime Ministerial speech (8 } \\
\text { March, 2012) and } 3 \\
\text { Presidential speeches (14 Sept. } \\
\text { 2012, } 20 \text { Sept., } 1 \text { Oct. } 2013 \text { ) }\end{array}$ & $\begin{array}{l}\text { http://www.ambafrance } \\
\text {-at.org/Surete- } \\
\underline{\text { nucleaire-extraits-du }}\end{array}$ \\
\hline \multirow{2}{*}{ Japan } & 4 (before) & \multirow{2}{*}{ English } & $\begin{array}{l}\text { Prime Minister ( } 3 \text { by } \\
\text { Yukio Hatoyama and } \\
1 \text { by Abe Shinzo) }\end{array}$ & $\begin{array}{l}4 \text { Prime Ministerial speeches } \\
\text { (18 Jan. 2011, } 12 \text { April } 2010 \\
\text { and10 June, 26 Oct. 2009) }\end{array}$ & \multirow[t]{2}{*}{$\begin{array}{l}\text { http://www.kantei.go.jp } \\
\text { /foreign/index-e.html }\end{array}$} \\
\hline & 5 (after) & & $\begin{array}{l}\text { Prime Minister } \\
\text { (Abe Shinzo) }\end{array}$ & $\begin{array}{l}5 \text { Prime Ministerial speeches } \\
\text { (4 Jan., } 28 \text { February, } 3 \text { May, } \\
18 \text { June, and } 7 \text { Sept. 2013) }\end{array}$ & \\
\hline Korea & 3 & English & $\begin{array}{l}\text { President ( } 1 \text { by Lee } \\
\text { Myungbak and } 2 \text { by } \\
\text { Park Geunhye) }\end{array}$ & $\begin{array}{l}3 \text { Presidential speeches (22 } \\
\text { September 2011, } 9 \text { May 2013, } \\
\text { and } 29 \text { June 2013) }\end{array}$ & $\begin{array}{l}\text { http://www.president.g } \\
\text { o.kr/president/speech.p } \\
\text { hp }\end{array}$ \\
\hline
\end{tabular}

